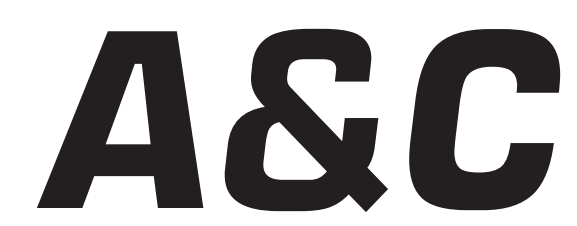

Revista de Direito Administrativo \& Constitucional

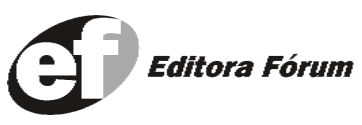

A\&C R. de Dir. Administrativo e Constitucional, Belo Horizonte, ano 5, n. 22, p. 1-253, out./dez. 2005 


\section{A\&C REVISTA DE DIREITO ADMINISTRATIVO E CONSTITUCIONAL}

\section{IPDA}

Instituto Paranaense

de Direito Administrativo

Direção Geral

Romeu Felipe Bacellar Filho

Direção Editorial

Paulo Roberto Ferreira Motta

Direção Executiva

Emerson Gabardo

Conselho de Redação

Edgar Chiuratto Guimarães

Adriana da Costa Ricardo Schier

Célio Heitor Guimarães

Conselho Editorial

Adilson Abreu Dallari

Alice Gonzáles Borges

Carlos Ari Sundfeld

Carlos Ayres Britto

Carlos Delpiazzo

Cármen Lúcia Antunes Rocha

Celso Antônio Bandeira de Mello

Clèmerson Merlin Clève

Clóvis Beznos

Enrique Silva Cimma

Eros Roberto Grau

Fabrício Motta

Guilhermo Andrés Muñoz (in memoriam)

Jaime Rodríguez-Arana Muñoz

Jorge Luís Salomoni
José Carlos Abraão
José Eduardo Martins Cardoso

José Luís Said

José Mario Serrate Paz

Juan Pablo Cajarville Peruffo

Juarez Freitas

Julio Rodolfo Comadira

Luís Enrique Chase Plate

Lúcia Valle Figueiredo

Manoel de Oliveira Franco Sobrinho

(in memoriam)

Marçal Justen Filho

Marcelo Figueiredo

Márcio Cammarosano

Maria Cristina Cesar de Oliveira
Nelson Figueiredo

Odilon Borges Junior

Pascual Caiella

Paulo Eduardo Garrido Modesto

Paulo Henrique Blasi

Paulo Neves de Carvalho (in memoriam)

Paulo Ricardo Schier

Pedro Paulo de Almeida Dutra

Regina Maria Macedo Nery Ferrari

Rogério Gesta Leal

Rolando Pantoja Bauzá

Sérgio Ferraz

Valmir Pontes Filho

Yara Stropa

Weida Zancaner

\footnotetext{
A246 A\&C Revista de Direito Administrativo e Constitucional. ano 3, n. 11, jan./mar. 2003. Belo Horizonte: Fórum, 2003.

Trimestral

ano 1, n.1, 1999 até ano 2, n.10, 2002 publicada pela Editora Juruá em Curitiba

ISSN: 1516-3210

1. Direito Administrativo. 2. Direito Constitucional. I. Fórum.
}

CDD: 342 CDU: 33.342

(c) Editora Fórum Ltda. 2005

Todos os direitos reservados. É proibida a reprodução total ou parcial, de qualquer forma ou por qualquer meio eletrônico ou mecânico, inclusive através de processos xerográficos, de fotocópias ou de gravação, sem permissão por escrito do possuidor dos direitos de cópias (Lei $n^{\circ}$ 9.610, de 19.02.1998).

Editora Fórum Ltda

Av. Afonso Pena, 2770 - 15\%16ªndar - Funcionários

CEP 30130-007 - Belo Horizonte/MG - Brasil

Tel.: 08007043737

Internet: www.editoraforum.com.br

e-mail: editoraforum@editoraforum.com.br
Editor responsável: Luís Cláudio Rodrigues Ferreira Projeto gráfico e diagramação: Luis Alberto Pimenta Revisora: Olga M. A. Sousa

Pesquisa jurídica: Fátima Ribeiro - OAB/MG 74868

Bibliotecária: Nilcéia Lage de Medeiros

CRB 1545/MG 6a região

Os conceitos e opiniões expressas nos trabalhos assinados são de responsabilidade exclusiva de seus autores.

Impressa no Brasil / Printed in Brazil

Distribuída em todo Território Nacional 


\title{
A Regulação e a Regulação Neoliberal
}

Paulo Roberto Ferreira Motta

Doutor em Direito pela UFPR. Professor de Direito Administrativo

E se mais houvera mais haveriam chegado.

Camões. Os Lusíadas

\begin{abstract}
Sumário: Introdução - A regulação como ideologia - A crise (ou a morte) do Estado Social - A transferência de modelos jurídicos - A fuga do direito administrativo - "O poder regulador" e a função regulatória - A função regulatória - A delegificação - Conclusão
\end{abstract}

\section{Introdução}

A regulação, assim como a globalização, é uma moeda de duas faces. Ela nunca deixou de existir, ainda que com outras nomenclaturas: poder de polícia, relação de especial sujeição, etc. Do mesmo modo a globalização. Como diz Mestre Paulo Bonavides, "a globalização em curso no mundo contemporâneo se compreende melhor como espécie e não como gênero. Posta em termos de rigidez que exclui alternativas e inculca determinismo e fatalidade, privando a sociedade da esfera onde ela exercita a autodeterminação, o livre arbítrio e a soberania, a globalização é absolutamente falsa". ${ }^{1}$

Assim, tal e qual a globalização, a regulação pode ser a face do colonialismo, e todas as suas nefastas conseqüências, mas pode ser a outra, a da "civilização e progresso; caminho para a liberdade e para o advento da quarta geração de direitos fundamentais, aqueles fadados a redimir na paz, na democracia, e no pluralismo a sociedade da cidadania". ${ }^{2}$

\section{A regulação como ideologia}

O sistema econômico denominado de neoliberalismo, que tudo transforma em mercadoria, adquire sua força exatamente pelas promessas que faz, e que jamais cumpre. Promete riqueza, novas formas de produzir, novas maneiras de distribuir as benesses do trabalho e do capital, mas somente produz, e distribui, o seu subproduto: a miséria. As riquezas são

\footnotetext{
1 BONAVIDES, Paulo. Do País Constitucional ao País Neocolonial: a Derrubada da Constituição e a Recolonização pelo Golpe de Estado Institucional. São Paulo: Malheiros, 1999, p. 15-16.

2 Id., p. 16.
} 
acumuladas pelas instituições que já são ricas e poderosas. Na sua ânsia desesperada de transformar todas as coisas em mercadorias, prega que a produção normativa deve ser célere e imediata, razão pela qual os corpos legislativos perdem, pela força mitológica, a competência de produzir o Direito, sendo a tarefa assumida pelas agências de regulação.

Para convencer - eis que jamais demonstra o que promete - basicamente prega que o Estado Social, que propiciou o resgate de milhões de seres humanos em todos os rincões da Terra, das condenações que sofreram por outras exclusões, morreu. Ou, quando muito, descreve uma crise, que, segundo os fundamentos filosóficos do neoliberalismo, é irreversível. Quer na certidão de óbito, quer na irreversibilidade das coisas, o neoliberalismo, demonstrando a indigência de sua formulação teórica original, realiza sempre o mesmo diagnóstico e prescreve sempre o mesmo receituário. Não importa o doente. A fórmula jamais varia.

Assim, o diagnóstico pode ser resumido numa única frase: o Estado Social morreu; se ainda vive, está em crise e, conseqüentemente, morrerá. Caso insista em viver — ou vegetar — , seus fundamentos teóricos e suas realizações materiais, devem ser retirados do mundo das idéias e dos fatos, preferencialmente, através de pancadas, até que o próprio cadáver suma da face da Terra.

As terapias, no Direito, que são as que nos interessam, do mesmo modo, são sempre as mesmas: preceituar que o Direito nacional é incapaz de regular as novas necessidades do país, devendo, portanto, abrir espaço ao estrangeiro, notadamente o do common law, de extração norte-americana. Fugir, rumo ao Direito privado, do Direito Administrativo. Introduzir novos institutos jurídicos ausentes da tradição doutrinária e jurisprudencial, e (pouco importa) violadoras das Constituições.

Passo, agora, a analisar cada um dos quatro tópicos antes enumerados.

\section{A crise (ou a morte) do Estado Social}

Negar que o Estado Social está em crise seria, induvidosamente, e pedindo excusas pela expressão, estupidez completa. Contudo, isto não pode ser entendido no sentido que pretendem aqueles que descrevem formulações que tentam convencer que o Estado Social e sua característica maior, os serviços públicos, estão mortos e merecem um enterro respeitoso (ou simplesmente o abandono do cadáver para que os corvos se alimentem). 
Outros sistemas também atravessaram crises e nem por isso tiveram lavrados seus atestados de óbito. Aliás, e sem que seja necessário tecer maiores considerações, o capitalismo vem sofrendo crises sucessivas desde o seu nascedouro, e nem por isso, a utopia marxista, que vislumbrava o final do mesmo, se materializou. Ao contrário, o capitalismo sempre saiu de suas crises ainda mais forte do que era, embora muitas vezes, como agora, absolutamente desumano e aético.

Em outros tempos, institutos jurídicos-constitucionais (dentre os quais encontramos o serviço público) também atravessaram crises fortíssimas no Brasil, como, por exemplo, a República, o Federalismo e o Presidencialismo, e, mesmo assim, continuaram presentes nas Constituições, e com idas e vindas, ainda existem e cumprem, nem sempre bem, é verdade, seus objetivos.

É induvidoso, apesar disso, que o capitalismo sempre teve, para sair das crises sucessivas em que mergulhava, dois poderosos aliados: o serviço público e a atividade econômica exercida pelo Estado. Para comprovar a correção da assertiva, vou buscar um considerável aporte num dos mais fidagais inimigos do serviço público que aduz ser o mesmo "merecedor de um grande elogio, já que foi um instrumento de progresso e também de socialização, especialmente nos Estados pobres, aos quais permitiu melhorar a situação de todos". Tal melhora, por certo absolutamente verdadeira, teve como ponto de partida "a técnica do serviço público" que "representou a grande revolução econômica e social dos últimos 150 anos, que deu lugar a um desenvolvimento sem precedentes da humanidade: sucessivas revoluções industriais e tecnológicas, processos de igualdade social, educação generalizada, atenção sanitária praticamente universalizada e um progresso sustentado de liberdade”. As palavras acima reproduzidas pertencem ao professor espanhol Gaspar Ariño Ortiz. ${ }^{3}$

Ao declarar morto tão nobre, poderoso e revolucionário instituto jurídico, a vontade manifesta, muito embora não revelada, não pode ser outra, do que tentar impedir, mesmo que pela via reflexa, a educação generalizada, a atenção sanitária praticamente universalizada e um progresso sustentado de liberdade, tornando, assim, ainda mais real e escancarado o caráter excludente do neoliberalismo.

Deste modo, pretender uma regulação que substitua o serviço público pelo mercado é falacioso e somente poderia ser comparada à fábula

\footnotetext{
3 ARIÑO ORTIZ, Gaspar. Princípios de Derecho Público Econômico, Modelo de Estado, Gestión Pública, Regulación Econômica. Granada: Comares, 1999, p. 550.
}

A \& C R. de Dir. Administrativo e Constitucional, Belo Horizonte, ano 5, n. 22, p. 59-99, out./dez. 2005 
da galinha dos ovos de ouro, pois de outro modo não haveria desenvolvimento econômico. A lógica sustentada, deste modo, apenas pode permitir a conclusão de duas coisas antinômicas, sendo, por elementar, uma falsa e outra verdadeira.

Primeira, a falsa. O neoliberalismo estaria contrariando os paradigmas fundamentais do capitalismo, que sempre teve no serviço público (assim como a atividade econômica exercida pelo Estado) o combustível necessário para gerir seus saltos de qualidade (como a educação das massas trabalhadoras, para fazer frente aos novos desafios tecnológicos; a expansão das redes sanitárias, para que a força de trabalho não viesse a sofrer males que a afastasse do mesmo; seguros-desemprego, para os exércitos de reserva de mão de obra, indispensáveis para a legitimação do sistema, etc.). ${ }^{4}$ Tal constatação, a de que o neoliberalismo estaria contrariando os paradigmas fundamentais do capitalismo, seria absurdo atroz, e evidentemente se traduz, como antes dito, em uma falsa conclusão.

A segunda conclusão é a que pode ser verdadeira. No atual estágio do desenvolvimento do capitalismo, ou seja, o neoliberalismo, a universalização das conquistas tecnológicas da humanidade não é eficiente e eficaz para o sistema econômico dominante. Isso, pela elementar razão de que não há lugar para todos, pois as estruturas, para serem universalizadas, demandam extraordinário capital e o retorno do mesmo é lento e, em alguns casos, completamente inexistente para os agentes privados do mercado. Explico: incluir todos custa muito caro e o retorno dos investimentos, bem como o percentual dos mesmos, não é eficaz, para remunerar capitais que ganham muito mais, em muito menos tempo, nos mercados periféricos, que, ao estribarem seus sistemas econômicos no modelo neoliberal, necessitam, desesperadamente, de aportes de dinheiro estrangeiro, nem que o mesmo utilize estas nações como - e pedindo mais uma vez excusas pela expressão grotesca a seguir utilizada - "motéis de alta rotatividade". Ou seja, não fazer é muito mais lucrativo do que fazer.

Por esta razão, o serviço público, que é includente pela sua própria natureza, e requer grandes aportes, fundamentalmente na construção e manutenção de estruturas e redes, deve ser substituído pelo mercado, que, ao selecionar as mercadorias pelo valor puramente econômico das mesmas, se torna excludente. Tais pressupostos, ideológicos, é que permitem a conclusão, por certa parte da doutrina, de que o Estado Social está morto,

\footnotetext{
${ }_{4}$ Aprofundar em OFFE, Claus. Capitalismo Desorganizado. São Paulo: Brasiliense, 1984, passim. VOGT,
} Winfried; FRANK, Jurgen; OFFE, Claus. Estado e Capitalismo. Rio de Janeiro: Tempo Brasileiro, 1980, passim.

A \& C R. de Dir. Administrativo e Constitucional, Belo Horizonte, ano 5, n. 22, p. 59-99, out./dez. 2005 
levando consigo, para o túmulo, o serviço público.

Sustenta Fábio Ulhoa Coelho que é possível ver a questão da crise do Estado Social sob duas óticas, uma marxista e outra liberal. Segundo a análise marxista, o "Estado não é mais ou menos intervencionista em função de critérios científicos, econômicos ou em função de opções livres que pessoas tomam reunidas em assembléias constituintes. O Estado é mais ou menos intervencionista em função das necessidades de preservação do sistema econômico dominante". ${ }^{5}$

Assim, "Pois bem, o socialismo fracassou. Caiu o Muro de Berlim. Não há mais por que manter estes gastos. O Estado, por conseqüência, retrai-se no fim do século XX, uma vez que não é mais necessário gastar com coisas que se justificavam num momento de guerra. (...) A História não para. Os conflitos de classe continuam. O capitalismo, por enquanto, não enfrenta perigo algum. Daqui a 20 ou 30 anos pode ser que esteja enfrentando novos riscos de sobrevivência. E, então, o que poderá acontecer? Ora, a burguesia irá usar, novamente, o Estado para uma maior intervenção". ${ }^{6}$

Dentro da análise liberal, segundo o mesmo Fábio Ulhoa Coelho, teríamos o desmantelamento do Estado Social em virtude do chamado custo Brasil, que "representa o quanto do preço de produtos ou serviços fabricados ou comercializados no Brasil acresce em função de o Estado Brasileiro ser maior do que deveria. Desta forma, se a empresa brasileira competir com a de um Estado mais liberalizado talvez nem consiga, simplesmente, competir. O economista liberal diria, portanto, que o Estado está reduzido porque, caso não o fizesse, as empresas brasileiras não iriam encarar a competição com as empresas internacionais, que vivem num cenário liberal. Num mundo globalizado, estas empresas são as nossas concorrentes. Se o empresário brasileiro deve pagar mais contribuições sociais para a Previdência, ele não pode praticar preço competitivo com os dos seus concorrentes globais. A globalização força a reliberalização do Estado, na visão dos teóricos liberais". ${ }^{7}$

De qualquer forma, "optando pela análise marxista ou pela análise liberal, o fato é que o Estado está se livrando de um ônus que, durante o século XX, chamou para si, que é o da manutenção de algumas comodidades para todos os cidadãos: a Educação, a Saúde, a Previdência Social, 5 COELHO, Fábio Ulhoa. Reforma do Estado e Direito Concorrencial. In: SUNDFELD, Carlos Ari. Direito Administrativo Econômico. São Paulo: Sociedade Brasileira de Direito Público, Malheiros, 2000, p. 192.

6 Op. cit., p. 192.

7 Id., p. 193.

A \& C R. de Dir. Administrativo e Constitucional, Belo Horizonte, ano 5, n. 22, p. 59-99, out./dez. 2005 
etc." sustenta Coelho. ${ }^{8}$

Esta crença, de que o Estado Social perdeu o sentido, vincula-se, no campo jurídico, com outra, qual seja, a de que o regime jurídico deste mesmo Estado Social tenha que ser suplantado por outro.

Neste teatro de operações surgem idéias de que, em virtude da globalização econômica, o intérprete do Direito deve buscar base doutrinária em outros princípios, fora dos tradicionais, como, por exemplo, o da separação dos Poderes e o da legalidade estrita.

Penso, radicalmente ao contrário, que o alerta de Jesús Leguina Villa é fundamental para a colocação do problema gerado pela crise do Estado Social em relação ao Direito Público, notadamente o Administrativo: "Uma coisa é a redefinição do Direito Administrativo, outra, muito distinta, sua liquidação pura e simples". ${ }^{9}$

A preocupação, no meu modo de entender, não passa pela liquidação pura e simples do Direito Administrativo e de seus postulados fundamentais (onde estão localizados, por suposto, os princípios da separação dos Poderes e da legalidade estrita). Primeiro, porque seria insustentável a posição de se derrogar, pura e simplesmente, todo um processo de acumulação cultural, como se o mesmo pudesse ser desprezado e substituído por outro, cujas raízes estão distantes das nossas origens e aspirações. Segundo, porque a substituição da separação dos Poderes e da legalidade estrita por um Direito Administrativo destituído de principiologia e tornado amorfo por importações irrefletidas geraria, apenas e tão-somente, um vazio principiológico, comportando uma exegese irresponsável, não social e contrária à dignidade da pessoa humana. Implicaria, assim, em adotar um conjunto normativo nascido de outras experiências, que não as nossas, brasileiras, como se fosse possível uma dicção que nega a aplicação material dos direitos constitucionais.

Além do mais, e voltarei, a seguir, a este ponto, o Direito brasileiro possui uma imensa e profunda (no tempo e na qualidade) experiência regulatória, que permitiu (aos trancos e solavancos muitas vezes, reconheçase) imensos avanços no campo dos direitos fundamentais da pessoa humana, incorporando à escola pública e ao sistema estatal de saúde, somente para apontar dois campos, milhões de compatriotas.

\footnotetext{
8 Ibid., p. 193.

9 LEGUINA VILLA, Jesús. A Constituição Española e a Fuga do Direito Administrativo. RDAA, 6, p. 639.
} 
Creio, também, que no atual estágio da democracia brasileira não se pode produzir ciência com preconceitos nascidos de mythos, como se a produção jurídica pudesse ser realizada por magos e bruxas que ficam recitando, perante os caldeirões, a mesma ladainha de sempre. Prática que, convenhamos, com alguma certeza, em relação ao método, e com muita fé, em termos de resultado, pode muito bem ser resolvida pela psicanálise.

É nesse clima, funesto por certo, que prosperam idéias de que tudo que provém do Estado é imprestável (mythos) e que o mercado somente faz brotar coisas maravilhosas (mythos). Se há uma verdade na ineficiência do Estado em muitos setores (logos), o mesmo se pode dizer do mercado (logos). Se o Estado tem problemas de eficiência, notadamente na gestão e aplicação dos recursos arrecadados, a culpa não cabe, exclusivamente, ao mercado (logos). Se o mercado tem problemas de eficiência, de alguma forma, há responsabilidade do Estado por este fato (logos). Assim, Estado e mercado podem se complementar, atuando mutuamente (logos), tarefa extremamente difícil (logos), na busca de uma eficiência econômica que permita a universalização dos serviços públicos. ${ }^{10}$

Lembro, dando apenas um único exemplo, que o Estado brasileiro foi capaz, em poucos anos, às suas próprias expensas, sem um mísero dólar estrangeiro, de informatizar todas as seções eleitorais do país, exporta esta tecnologia para outros países e deixa a nação mais poderosa do mundo embasbacada com a possibilidade de realizar com extrema rapidez a totalização dos votos. Por outro lado, alguns dos institutos de pesquisa, agentes do mercado da informação, sistematicamente erram seus prognósticos, não somente nos percentuais de voto, como, inclusive, e o que é mais grave e atentatório ao Estado de Direito, sobre os vencedores dos pleitos.

Narrando outras experiências, mas comportando a possível utopia

\footnotetext{
${ }^{10}$ A tarefa é extremamente difícil. Veja-se Cristiane Derani: "Serviço público surge e cresce com a instauração e predominância das relações produtivas de mercado na sociedade. O serviço público é o companheiro estimado do mercado, necessário a sua instituição e impregnação nos mais recônditos veios das relações sociais. Cabe dar ao serviço público o crédito de ser o responsável pelo grau de desenvolvimento em que se encontram as relações capitalistas nos estertores do milênio. Serviço público e mercado são expressões da ambigüidade dos valores do homem moderno. Em comum, carregam o antagonismo da sociedade moderna de liberdade individual e comprometimento social. São dois mastros opostos entre os quais viria para a manutenção da sociedade moderna. São instrumentos interdependentes para sua manifestação e utilidade. Um perde a razão de ser sem o outro. Distintos, opostos, atados pela sociedade que pretendem manter. O indivíduo livre age na sociedade, na vida econômica (liberdade de iniciativa, liberdade de iniciativa de mercado) movido por interesses próprios, com finalidades individuais. O Estado, detentor do poder público, age na sociedade e no mercado movido pelo interesse público com finalidades sociais". Privatização e Serviços Públicos: as Ações do Estado na Produção Econômica. São Paulo: Max Limonad, 2002, p. 64-65.
} 
de incorporar e incluir os compatriotas nos sistemas produtivos, exatamente por abandonar certos mythos falsos e ladainhas inúteis, o professor espanhol Jaime Rodríguez-Arana Muñoz sustenta que a Administração Pública do Estado Social e Democrático de Direito só pode adquirir a sua configuração jurídica através da observância dos princípios da legalidade, da eficácia ${ }^{11}$ e dos serviços públicos. ${ }^{12}$ "Legalidade, porque o procedimento administrativo não é outra coisa que um itinerário pensado para salvaguardar os direitos e interesses legítimos dos cidadãos". ${ }^{13}$ "Eficácia, porque hoje é perfeitamente possível exigir que a organização administrativa ofereça produtos e serviços de qualidade". ${ }^{14}$ "E serviços, sobretudo, porque não se pode esquecer que a justificação da existência da Administração se encontra nos serviços que atendam aos interesses coletivos. Por isso, as distintas intervenções e o exercício dos poderes públicos são manifestações concretas dessa idéia de serviço público". ${ }^{15}$

Interessante notar, ainda, como faz Rodríguez-Arana Muñoz, que mesmo em nações de alto desenvolvimento econômico, setores cada vez mais amplos da sociedade consideram que o mercado não pode ser o senhor e proprietário da Administração Pública, submetendo-a aos seus caprichos e ansiedades. Lembra o citado autor ibérico que o Informe Al Gore (vice-presidente de Bill Clinton), intitulado "Criar uma Administração Pública que funcione melhor e custe menos", é o punctum dolens de "qualquer processo de reforma ou modernização administrativa e que se tenha bem claro que o dono, o proprietário da Administração Pública, é o cidadão; que quem manda é o cidadão e que a Administração se justifica, não só constitucionalmente, como uma organização ao serviço do interesse geral". ${ }^{16}$

Tal fato, de há muito, é inteiramente compreendido pela doutrina,

\footnotetext{
${ }^{11}$ Não há uma exata correspondência entre as expressões eficácia e eficiência no direito espanhol. "No plano constitucional, eficiência e eficácia aparecem nitidamente distintos: a) eficiência se recolhe na parte dogmática ou substantiva, no contexto dos recursos econômicos públicos e em estreita vinculação com o valor-princípio da economia (art. 31.2, Constituição espanhola). (...) A eficácia, contrariamente, se recolhe na parte organizativa e com fixação do estatuto subjetivo principal de uma precisa organização da Administração Pública (art. 103.1 CE), a que corresponde ao desenvolvimento da função executiva. (...) A Administração Pública há de atuar, assim, conforme, entre outros, segundo o princípio da eficácia (sem prejuízo da submissão plena à Lei e ao Direito)." PAREJO ALFONSO, Luciano. Eficácia y Administración: Tres Estúdios. Boletín Oficial del Estado, Madrid, 1995, p. 100, traduzi.

12 RODRÍGUEZ-ARANA MUÑOZ, Jaime. Reformas y Modernización de la Administración Española. In: RODRÍGUEZ-ARANA MUÑOZ, Jaime; CALVO CHARRO, Maria (Coord.). La Administración Pública Española. Madrid: Instituto Nacional de Administração Pública, 2002, p. 17 et seq., traduzi. No Direito brasileiro, em abordagem paralela, realçando a democracia, deve ser considerado o magnífico estudo de ROCHA, Carmem Lúcia Antunes. Democracia, Constituição e Administração pública. RDTP, 26, p. 60-67.

13 Op. cit., p. 17.

14 Id.

15 Ibid.
} 
e possui sólidas raízes no Direito brasileiro, bastando, para tanto, invocar a teoria do interesse público primário e secundário. ${ }^{17}$

Nestes termos, alvorece, com grande intensidade, no Direito Administrativo e o regime-jurídico que lhe é próprio, ou seja, aquele que estabelece a supremacia do interesse público sobre o privado e a indisponibilidade dos interesses públicos pela Administração, a idéia desenvolvida por Celso Antônio Bandeira de Mello de que compete ao Estado dar guarida permanente "aos interesses qualificados como próprios da coletividade" que "não se encontram à livre disposição de quem quer que seja, por inapropriáveis". ${ }^{18}$

É induvidoso, portanto, que qualquer reforma regulatória que retire a primazia da cidadania e entregue a mesma, exclusivamente, ao mercado estará, no tempo e no espaço, traindo o Direito que a idealizou e, portanto, fadada ao fracasso, por incoerência metodológica, ocasionada pela ausência de cientificidade. No campo ético, implica no desespero de milhões de seres humanos, mesmo nos países altamente desenvolvidos. Nos subdesenvolvidos o processo apenas adquire maior, e mais perversa, dramaticidade.

Para Rodríguez-Arana Muñoz, a crise do Estado Social repousa no fato de que as atuais Administrações cresceram burocraticamente, olvidando-se por completo da cidadania, nas suas expressões e necessidades coletivas e individuais. Assim, o grau de deformidade chegou a ponto de que determinadas Administrações Públicas (logos, mais uma vez) se bastarem por si mesmas, esquecendo-se das suas atividades finalísticas. ${ }^{19}$

Posso concluir, então - e a conclusão é minha e não do autor citado, faço questão de fazer constar — que a deformidade havida na Administração Pública se deve ao fato de que a cidadania demorou a perceber o fenômeno, e não tomou, no devido tempo e lugar, as providências que lhe competiam. Assim, uma regulação que despreze a cidadania e favoreça, exclusivamente, o mercado, ao contrário das ladainhas de sempre, não fortalece o país sistemicamente, mas, ao contrário, o enfraquece. Volta-se, por suposto, mais uma vez, à ausência de cientificidade das

\footnotetext{
${ }^{16}$ Op. cit., p. 22.

${ }^{17}$ A doutrina foi desenvolvida, no direito brasileiro, estribada nos aportes desenvolvidos por Renato ALESSI, por BANDEIRA DE MELLO, Celso Antônio. Curso de Direito Administrativo. 14. ed. São Paulo: Malheiros, 2002, p. 69 et seq. Em relação ao interesse público e a regulação há obra de MARQUES NETO, Floriano de Azevedo, dedicada ao tema, com aportes nitidamente diferenciados deste trabalho, Regulação Estatal e Interesses Públicos. São Paulo: Malheiros, 2002, passim. Cf., com aportes diversos, também JUSTEN FILHO, Marçal. Conceito de Interesse Público e a 'Personalização' do Direito Administrativo. RTDP, 26, p. 115-136.

18 BANDEIRA DE MELLO, Celso Antônio. Curso..., p. 45.

${ }^{19}$ Id., p. 23.
}

A \& C R. de Dir. Administrativo e Constitucional, Belo Horizonte, ano 5, n. 22, p. 59-99, out./dez. 2005 
referidas formulações jurídicas neoliberais no ramo jurídico do Direito Administrativo.

Ademais, apesar dos aportes financeiros do Estado terem crescido, através do aumento significativo dos percentuais orçamentários aplicados nas áreas sociais, a mentalidade esclerosada e conservadora que contaminou a Administração aplica estes recursos para as "maiorias clientelares, sem projeto vital, o que pode se converter em um câncer da vida social”. ${ }^{20}$ Neste tópico, o do atendimento das demandas clientelares sem projeto para o país, o Brasil, lamentavelmente, é exemplo, nada dignificante, desde os temos coloniais do Império Ultramarino português até os dias atuais, sem que haja, no horizonte, próximo ou remoto, qualquer sinal de término de tão pavorosa prática.

Demonstra o referido autor espanhol sua preocupação, com a seguinte construção, que, na minha opinião, sepulta o mytho e restaura o logos: "Sirva como exemplo a ação do Estado em relação aos grupos coletivos mais desfavorecidos, os que - por motivos diferentes - são qualificados como marginalizados, desempregados, pobres e velhos. Os gastos do Estado nunca poderiam ser considerados por eles como dádivas mecânicas, ao contrário, o Estado deve proporcionar com as suas prestações o desenvolvimento, a manifestação, o afloramento das energias e das capacidades que estão escondidas nestes amplos setores sociais e que tendem a uma manifestação adequada para a aparição de iniciativas individuais e associativas. Um projeto deste tipo permitiria afirmar claramente a plena compatibilidade entre a esfera dos interesses da empresa e da justiça social, já que as tarefas de redistribuição da riqueza devem ter um caráter dinamizador dos setores menos favorecidos, não conformista. Ademais, permitirá, igualmente, conciliar a necessidade de manter os atuais níveis de bem-estar e a necessidade de realizar ajustes na priorização dos gastos estatais, o que se traduziria em uma maior efetividade do esforço redistributivo." ${ }^{11}$

Por derradeiro, Rodríguez-Arana Muñoz coloca a questão fundamental que deve informar a regulação, qual seja, a de que o Estado deve atuar para criar uma competição econômica sadia entre os agentes do mercado, e "não atuar entorpecendo o processo econômico da livre

\footnotetext{
20 Ibid., p. 28.

${ }^{21}$ Id., p. 28-29.
} 
competição". ${ }^{22}$ Assim, qualquer transformação do modelo do Estado jamais poderá afetar os objetivos sociais defendidos pelo Estado de bem-estar.

Ao Estado Social compete abandonar o enfoque negativo (a indigência, a doença, a ignorância, a miséria e a indolência) e atuar no sentido positivo (a autonomia, a saúde, a educação, a riqueza, o trabalho). ${ }^{23}$ Acrescento, portanto, mais uma vez, que a regulação que transforma homens em mercadorias é contrária à Constituição e ao Direito. A que transforma indigentes em seres dotados de autonomia consciente de vontade, doentes em sadios, ignorantes em educados, miseráveis em usuários, indolentes em trabalhadores, é a regulação que deve ser perseguida.

A atividade estatal, portanto, não pode prescindir do serviço público universal. Em sendo assim, a crise do Estado Social, ao contrário do que sustentam ideologicamente os neoliberais, não passa pela eliminação do mesmo, mas sim pelo direcionamento do aparelhamento estatal às maiorias interessadas no desenvolvimento de suas situações individuais e coletivas. Não passa, portanto, pela mercantilização dos processos humanos, mas sim pela dignificação destes. E, fundamentalmente, não passa pelo genocídio de culturas jurídicas diferentes das do Common Law e, historicamente, estratificadas nas mentes das pessoas.

\section{A transferência de modelos jurídicos}

Falar de regulação sem enfrentar a questão das transferências de modelos jurídicos de um país para outro ${ }^{24}$ seria erro tremendo e irrecuperável. Respeitosamente, não entendo como parte da doutrina publicista assim vem procedendo. Vislumbro neste método, além da evidente acriticidade, uma metodologia que corre o risco de nada significar para aquilo que interessa, ou seja, a construção de uma dogmática jurídica que atenda à nova realidade vivida pelo país, a partir das reformas privatizantes, que foram iniciadas desde a primeira metade da década de noventa do século anterior.

Quero, com isso, afirmar, até mesmo para evitar mal entendidos,

\footnotetext{
22 Ibid., p. 32.

${ }^{23}$ Ibid., p. 33. O tema pode ser aprofundado em VILLORIA MENDIETA, Manuel. La Modernización como Instrumento al Servicio de la Democracia. Boletín Oficial del Estado, Madrid, 1996, todo.

24 Segundo YAZBEK, Otávio no seu artigo "Considerações sobre a Circulação e Transferência dos Modelos Jurídicos", a apontada transferência de modelos jurídicos, de um país para outro, pode ser definida como "a adoção, por uma dada população, de regras, práticas ou concepções jurídicas próprias de outro povo", in GRAU, Eros Roberto; GUERRA FILHO, Willis Santiago (Org.). Direito Constitucional: Estudos em Homenagem a Paulo Bonavides. São Paulo: Malheiros, 2001, p. 543.
} 
que concordo plenamente com Renato Janine Ribeiro quando sustenta que "é desnecessário dizer que não defendo nenhum fechamento sobre si, nenhuma patriotada cultural. Tudo que é bom deve ser incorporado, venha de onde vier. O que critico é o viés subalterno, a subserviência." ${ }^{25}$

Fala-se, e mais uma vez averbo a acriticidade de tal postura, que a regulação dos serviços públicos (preferencialmente denominados de serviços de interesse geral, ou universal, ou econômico) é um processo jurídico cambiante. Ora, tal fato, para todos aqueles que conhecem um pouco de história do Direito, e, principalmente, a do Administrativo, não traz consigo nenhuma novidade. Basta dizer que, quando da popularização da energia elétrica em França, inúmeras foram as decisões do Conselho de Estado no sentido de que os concessionários do serviço de iluminação pública (na época, realizada por lampiões a gás) deveriam se adaptar à nova tecnologia (luz elétrica), sem prejuízos do reequilíbrio econômico do contrato. Veja-se, por elucidativo, um, dos vários precedentes do Conselho de Estado francês: "Conselho de Estado. Mutabilidade dos contratos. Poder de modificação unilateral. Conselho de Estado, 10 de janeiro de 1902. Nova Companhia de Gás de Deville-les-Rouen. "Um contrato de concessão que fora acordado com esta Companhia previu o monopólio de iluminação a gás na Comuna”. Alguns anos mais tarde, a iluminação por eletricidade se desenvolveu. A Comuna requereu à sua concessionária que assegurasse a iluminação por esta nova e melhor técnica, a fim de satisfazer às necessidades públicas, e, diante de sua recusa, se dirigiu a outra companhia de iluminação elétrica. Este negócio é uma das ilustrações que se qualificaram, na época, como contenda entre os fornecedores de iluminação a gás e de energia elétrica. Estimando seu monopólio violado, a Companhia de Gás reclamou uma indenização. O Conselho de Estado reconheceu o direito da Administração exigir de seu contratado uma adaptação às necessidades do serviço. Em certos casos, este direito é um verdadeiro dever, que obriga a Administração a modificar o regime de serviço, pois, caso contrário, os usuários poderiam exigir a sua responsabilização. O Conselho de Estado decidiu pela manutenção do contrato, reconhecendo o privilégio da Companhia de Iluminação a Gás de prestar o serviço conforme foi estipulado ou por qualquer outro modo. Todavia, reconheceu à Comuna o direito de ter assegurado, pelo menos, 1/3 do serviço, por meio de eletricidade, ainda que, no caso, houvesse recusa ${ }^{25}$ RIBEIRO, Renato Janine. A Sociedade Contra o Social: o Alto Custo da Vida Pública no Brasil. São Paulo: Companhia das Letras, 2000, p. 12.

A \& C R. de Dir. Administrativo e Constitucional, Belo Horizonte, ano 5, n. 22, p. 59-99, out./dez. 2005 
da Companhia concessionária devidamente instalada, modificando-se, assim, as condições do contrato, inicialmente estipuladas."

Nestes termos, anoto que no Direito brasileiro, desde há muito, juristas, como Francisco Campos, se debruçaram sobre o tema. Deste, colho parecer, exarado na década de 30 do século passado, na questão envolvendo o Governo Federal e a Société Anonyme du Gaz do Rio de Janeiro (prestadora do serviço de iluminação da referida cidade), tratando da alteração unilateral do contrato, pelo Governo, acabando com a cláusula do câmbio do par. ${ }^{26}$ No parecer emitido, contratado pela empresa francesa, Francisco Campos estabeleceu as seguintes conclusões, que demonstram, induvidosamente, a possibilidade de mudanças serem operadas nos contratos de concessão, desde que, e somente se, fosse observada a equação econômico-financeira do mesmo: "Se ao Estado é lícito alterar, em qualquer momento, por ato unilateral, tudo quanto se refira às condições do serviço, ao seu regime, à sua organização, ao seu funcionamento, às exigências criadas ao concessionário, no ato de concessão, no interesse do serviço público concedido, não poderá, porém, alterar a relação entre os termos da equação econômica ou financeira...."27

Decisões administrativas como as acima descritas, de resto recepcionadas pela jurisprudência pátria, levaram Caio Tácito a constatar que: "A partir de 1930, com a extinção praticamente simultânea das garantias de juros mínimos e do padrão ouro das tarifas, firma-se, em contrapartida, a regra constitucional de justa distribuição do capital de modo a assegurar a estabilidade dos contratos e a estimular o financiamento da expansão e melhoria das instalações." 28

A regulação realizada pelo velho e afrancesado serviço público também, e desde sempre, foi cambiante. No Direito brasileiro, em 1936, Manoel de Oliveira Franco Sobrinho já ensinava que a "concessão cria e reforma direitos", pois “o Estado (deve) é declarar direitos com restrições para que, mais tarde, não fique impossibilitado de opor barreiras a casos que se ontem eram plausíveis e justíssimos, hoje escondem, abominante acordo desvirtuador mesmo das funções superiores do Estado". ${ }^{29}$

No mesmo sentido, Oswaldo Aranha Bandeira de Mello, em magistério perfeito, escreveu que se os termos contratuais da concessão não ${ }^{26}$ Pela qual as tarifas eram fixadas em $50 \%$ pela moeda nacional e a outra metade em moeda estrangeira, razão pela qual foram as mesmas reajustadas sempre que houve variação cambial. Sobre outro instrumento, bastante utilizado na época, a cláusula-ouro, consultar CARVALHO PINTO, Carlos Alberto A. A Cláusulaouro nas Concessões de Serviço Público. São Paulo: Prefeitura do Município de São Paulo, 1943.

${ }^{27}$ CAMPOS, Francisco. Direito Administrativo. Rio de Janeiro: Freitas Bastos, 1958, v. I, p. 81-82.

${ }^{28}$ CAIO TÁCITO. Temas de Direito Público: Estudos e Pareceres. Rio de Janeiro: Renovar, 2002, v. 3, p. 12. 
pudessem ser alterados, em virtude do interesse público, o instituto "deveria ser eliminado, pelo fato de constituir sistema contrário ao interesse coletivo e significando esse interesse a razão de ser mesmo do serviço instituído." 30

Aliás, como sabem todos os que se dedicam ao estudo do Direito Público, não existe característica mais cambiante do que a manutenção do equilíbrio econômico-financeiro original do contrato de concessão de serviço público, assim como a aplicação, quando da existência de qualquer das inúmeras hipóteses de incidência, da teoria da imprevisão nos contratos administrativos, entre os quais se encontram, dentre outros, quaisquer formas de prestação de serviços públicos, onde há, na origem, uma outorga estatal. Neste caso, as mudanças havidas são de tal monta que podem até mesmo justificar o inadimplemento das cláusulas contratuais, sem que haja culpa e, conseqüentemente, qualquer sanção pela incidência da cláusula rebus sic stantibus.

Do mesmo modo, leio maravilhas sobre o conceito de public utilities e, sinceramente, somente consigo vislumbrar, de relevante, a diferença de que neste sistema, ao contrário do velho e afrancesado conceito de serviço público, não há ato administrativo de outorga. Tal fato, aliás, mestre Caio Tácito, em 1960, quando da sua tese de concurso para professor catedrático, já tinha verificado, quando ministrou que "a figura da transferência ou delegação de um serviço público, a concepção de que o Estado destaca uma parte de sua competência para atribuí-la à exploração do concessionário não se identifica no direito norte-americano". Com síntese admirável, temos que tal situação se dá em razão de que "todo serviço é privado, toda atividade econômica entende-se livre e franqueada à iniciativa particular. Certos serviços há, no entanto, incidindo a sua execução sob o controle do Estado, em virtude dos privilégios e deveres especiais que envolve". ${ }^{31}$

Leio, ainda, com certa surpresa, que a revolução havida no último decênio fará com que a concessão de serviço público encontre fatalmente a sua decadência, surgindo em seu lugar, com enorme esplendor, o instituto jurídico da autorização. Sinceramente, fico pasmo ao encontrar

\footnotetext{
${ }^{29}$ FRANCO SOBRINHO, Manoel de Oliveira. Concessão de Serviços Públicos em Direito Administrativo. Curitiba: 1936, p. 13-14.

${ }^{30}$ BANDEIRA DE MELLO, Oswaldo Aranha. Aspecto Jurídico-administrativo da Concessão de Serviço Público. $R D A, 26$, p. 17
} 
textos com esses conteúdos e penso que no Brasil, desde sempre, o número de pessoas (físicas ou jurídicas) autorizadas, licenciadas ou delegadas ao exercício de um serviço público é infinitamente maior do que o número de pessoas (físicas ou jurídicas) permissionárias ou concessionárias de serviços públicos. Para comprovar a assertiva não necessito de nenhum número mágico, de nenhuma estatística fantástica, de nenhuma pesquisa futura. Basta apontar a quantidade de médicos, dentistas, advogados, notários, registradores e escolas privadas. Todas as pessoas físicas e jurídicas antes citadas somente podem exercer as suas atividades profissionais e/ou comerciais depois de autorizadas, licenciadas ou titularizadas pela Administração Pública.

Tal evidência sempre foi destacada no Direito Administrativo brasileiro. Themístocles Cavalcanti, nesta senda, sempre sustentou que "a palavra concessão tem na teoria do Direito Administrativo os mais variados significados e aplicações diversas, embora seja a mesma usada especialmente em relação à exploração e execução dos serviços públicos". ${ }^{32}$ Sobre a existência, no Direito Administrativo brasileiro, de concessões, permissões e autorizações, Themístocles Cavalcanti afirma: "Os serviços públicos nem sempre são executados pelo Estado. Razões de ordem econômica e mesmo de ordem política e administrativa exigem que o Estado permita que terceiros executem serviços públicos. O Estado pode assim, apenas, autorizar, permitir, atribuir a terceiros, com as mesmas vantagens e os mesmos ônus, aqueles serviços. Daí a diferenciação técnica da simples autorização ou permissão da concessão. Na primeira categoria, compreendem-se as simples licenças, dadas de acordo com as leis e regulamentos por ato da administração pública." 33

De igual sorte, quando apresentado a novos institutos jurídicos, como a interconexão e o compartilhamento, ${ }^{34}$ bem como pelo uso de bens públicos dos Municípios ou dos Estados por empresas prestadoras de serviços públicos federais, não posso olvidar o que aprendi sobre limitações ao direito de propriedade, notadamente da restrição ou intervenção no atributo do uso. Mais uma vez, embrenhado na doutrina brasileira do passado não tão distante, encontro J. Guimarães Menegale, observando que "sabemos que

${ }^{31}$ CAIO TÁCITO. O Equilíbrio Financeiro na Concessão de Serviço Público. In: Temas de Direito Público: Estudos e Pareceres. Rio de Janeiro: Renovar, 1997, v.1, p. 213-214.

32 CAVALCANTI, Themístocles. Princípios Gerais de Direito Administrativo. 2. ed. Rio de Janeiro: Freitas Bastos, p. 269.

33 Op. cit., p. 270

A \& C R. de Dir. Administrativo e Constitucional, Belo Horizonte, ano 5, n. 22, p. 59-99, out./dez. 2005 
todos os indivíduos têm o poder legal de se servir do domínio público, segundo o uso a que foi destinado. De sorte que o direito de uso assiste aos entes públicos e aos particulares. Em ambos os casos, porém, o direito é de índole pública". Mais adiante, sustenta: "Para destrinçarem a questão do direito subjetivo ao uso do domínio público, numerosos autores se firmam em ponto de vista excludente do direito público, e, pois, principiam por defender a privatividade da relação jurídica entre os cidadãos, considerados singularmente, e a coisa pública. Vê-se de logo quanto é frágil a premissa que oblitera o dado essencial do domínio público, tentando submetê-lo a uma sistemática jurídica estranha à sua natureza." ${ }^{35}$

Inesquecível, ainda, no campo dos clássicos, a obra de Alberto Venâncio Filho, demonstrando que a regulação sempre existiu no Direito brasileiro, sendo denominada pelo autor como intervenção do Estado no Domínio Econômico, notadamente nos setores agrícola (café, açúcar, trigo, reforma agrária), da indústria extrativa (regime de minas, borracha, ervamate, pinho, sal), da indústria de transformação (águas, energia elétrica, petróleo, carvão, energia nuclear), no setor de transportes e comunicação (transporte ferroviário, transporte marítimo, setor portuário, transporte rodoviário, transporte aéreo, comunicações), no comércio (tabelamento de preços), no setor financeiro (bancos, mercado de capitais, regime do capital estrangeiro), no setor do comércio exterior (importação e exportação, regime de câmbio), no setor de seguros, na repressão dos abusos do poder econômico, além de estudar com profundidade a política de desenvolvimento regional estadual e de integração com os países latino-americanos. ${ }^{36}$

\footnotetext{
${ }^{34}$ Interconexão, segundo a definição normativa da ANATEL, exposta no inciso VI, do art. $3^{\circ}$ da Resolução n. 040/98, que aprovou o Regulamento Geral de Interconexão, é a ligação entre redes de telecomunicações funcionalmente compatíveis, de modo que os usuários de serviços de uma das redes possam comunicarse com usuários de serviços de outra ou acessar serviços nela disponíveis. O compartilhamento, conforme dispõe o "Regulamento conjunto para compartilhamento de infra-estrutura entre os setores de energia elétrica, telecomunicações e petróleo", baixado em conjunto pela ANEEL, ANATEL e ANP, em art. 30, V, "é o uso conjunto de uma infra-estrutura por agentes dos setores de energia elétrica, de telecomunicações ou de petróleo". A importância destes dois elementos técnicos é enorme. Através da utilização, conjunta, das estruturas já existentes, possibilitam-se o aumento, bem como a diversidade, dos serviços, oferecidos, passando-se, em conseqüência, a uma melhor qualidade. Ademais, possibilitam, também, a mais ampla competição entre as empresas prestadoras. É por isso que o Regulamento conjunto, antes citado, dispõe expressamente que: art. $4^{\circ}$. O agente que explora serviços públicos de energia elétrica, serviços de telecomunicações de interesse coletivo ou serviços de transporte dutoviário de petróleo, seus derivados e gás natural, tem direito a compartilhar infra-estrutura de outro agente de qualquer destes setores, de forma não discriminatória e a preços e condições justos e razoáveis, na forma deste Regulamento. Art. $5^{\circ}$. $\mathrm{O}$ atendimento a parâmetros de qualidade, segurança e proteção ao meio ambiente estabelecidos pelos órgãos competentes, assim como de obrigações associadas às concessões, permissões ou autorizações outorgadas ou expedidas pelo Poder Concedente e de boas práticas internacionais para prestação dos respectivos serviços, não deve ser comprometido pelo compartilhamento."

${ }^{35}$ MENEGALE, J. Guimarães. Direito Administrativo e Ciência da Administração. Direito Administrativo e Ciência da Administração. 2. ed. Rio de Janeiro, Borsoi, 1950, p. 33.
} 
Derradeiramente, mais uma vez há que se atribuir razão a Caio Tácito quando sustenta, até mesmo por ser um dos pioneiros do estudo da regulação no direito brasileiro, e, certamente, o seu decano, que "a aproximação, usualmente invocada, com o símile norte-americano e o de figuras equivalentes no plano do direito comparado, é antes terminológica do que real, em termos de substância." ${ }^{7}$

Deste modo, impossível não concordar com o preclaro Celso Antônio Bandeira de Mello, quando argumenta que noções como serviço público econômico "não servem para nada. É possível que, talvez, possam interessar a economistas ou politólogos, mas para a área jurídica seu préstimo é nenhum. Antes, é pior do que nenhum, pois só podem induzir a confusões e causar equívocos aos menos avisados." 38

Interessante ainda advertir, no campo das confusões e equívocos, aos menos avisados, que — com as exceções de Calixto Salomão Filho, ${ }^{39}$ Floriano Peixoto de Azevedo Marques Neto $^{40}$ e Marçal Justen Filho, ${ }^{41}$ que colheram os aportes doutrinários nos originais anglo-saxões, e Cristiane Derani, ${ }^{42}$ com farta doutrina contemporânea francesa - há uma verdadeira invasão de institutos jurídicos norte-americanos ou europeus comunitários advinda da doutrina espanhola, notadamente da lavra de Gaspar Ariño Ortiz. ${ }^{43}$

Destarte, se para o processo cognitivo do Direito Comunitário europeu não há problema maior, o mesmo já não se pode dizer do Direito norte-americano, importado através de traduções para o espanhol e, muitas vezes, (mal) (re)traduzido para o português.

Além do mais, sem nenhuma conotação de patrulha ideológica, mas sim como fato real, deve ser realizada a devida observação de que o nominado autor espanhol é representante extremado do neolibera-

\footnotetext{
${ }^{36}$ VENANCIO FILHO, Alberto. A Intervenção do Estado no Domínio Econômico: o Direito Público Econômico no Brasil. Rio de Janeiro: Renovar, 1998, passim.

${ }^{37}$ CAIO TÁCITO. Temas de Direito Público: Estudos e Pareceres, v. 3, p. 44.

38 BANDEIRA DE MELLO, Celso Antônio. Curso..., p. 606.

39 SALOMÃO FILHO, Calixto. Regulação e Desenvolvimento. São Paulo: Malheiros, 2002; Direito Concorrencial: as Estruturas. São Paulo: Malheiros, 1998; Regulação da Atividade Econômica: Princípios e Fundamentos Jurídicos. São Paulo: Malheiros, 2001, passim.

${ }^{40}$ MARQUES NETO, Floriano Peixoto de Azevedo, op. cit.

41 JUSTEN FILHO, Marçal, op. cit.

${ }^{42}$ DERANI, Cristiane, op. cit.

${ }^{43}$ ARIÑO ORTIZ, Gaspar. El nuevo Servicio Público (com a colaboração de DE LA CUÉTARA, J. M. \& LÓPEZ MUÑIZ, J. L. Martínez). Madrid: Marcial Pons, 1997; ARIÑO ORTIZ, Gaspar. Economía y Estado. Buenos Aires: Abeledo-Perrot, 1993; ARIÑO ORTIZ, Gaspar. La Regulación Económica: Teoría y Práctica de la Regulación para la Competencia. Buenos Aires: Ábaco, 1996; ARIÑO ORTIZ, Gaspar. Privatización y Liberalización de Servicios. Boletin Oficial del Estado, Madrid 1999. ARIÑO ORTIZ, Gaspar; LÓPEZ DE CASTRO, Lucía. El Sistema Eléctrico Español: Regulación y Competencia. Madrid: Fundación Ico: Fundación de Estudios de Regulación, 1988.
}

A \& C R. de Dir. Administrativo e Constitucional, Belo Horizonte, ano 5, n. 22, p. 59-99, out./dez. 2005 
lismo (o que, muitas vezes, passa despercebido pelos seus apressados intérpretes). ${ }^{44}$ Este fato, absolutamente realístico, repito, causa problemas constitucionais dos mais intensos em países que, como o Brasil, possuem Constituições consagradoras do Estado Democrático e Social de Direito.

Nestes termos, é precisa a observação de Maria Cristina César de Oliveira Dourado, quando critica o extremado neoliberalismo do autor espanhol, uma vez que a ideologia subjacente da posição "tem o condão de transformar em mercadoria todas as prestações produzidas pela sociedade, independentemente da natureza que possuam ou da finalidade a que se vinculem". ${ }^{45}$ Verticalizando a questão, nota a humanista autora que “a aparente neutralidade da construção técnica, genericamente aplicável a realidades distintas, mas sujeitas à lógica de um mercado globalizado, não toma em consideração a dimensão sociocultural e o papel de instrumento de garantia dos direitos fundamentais de que é dotada a noção de serviço público titularizada pelo Estado". ${ }^{46}$

Esta realidade, de desprezo da tradição doutrinária do direito pátrio e da utilização acrítica de aportes do direito estrangeiro, propicia, no plano vernacular, com profundas implicações para o Direito, o encontro de expressões em artigos doutrinários (muitas deles da maior densidade), como, por exemplo, publicatio e cometidos.

\footnotetext{
${ }^{44}$ Não estou ofendendo, e nem mesmo patrulhando, o autor. Apenas faço constar que "O neoliberalismo implica em uma tendência intelectual e política que prevalece, isto é, que tem preferencialmente as atuações econômicas dos agentes individuais, pessoas ou empresas privadas, sobre as ações da sociedade organizada em grupos informais (pensionistas), formais (associações de consumidores, sindicatos), associações políticas (partidos) e governos (...). O neoliberalismo professa que o mercado livre, incluindo o mercado real e concreto, mais ou menos livre, que temos hoje em dia, coordena adequadamente as ações individuais de caráter econômico para conseguir um acervo de riquezas maior do que se conseguiria com outros métodos de organização da economia (planejamento, intervenção estatal, incluindo a economia mista) (...). A regulamentação e o controle dos mercados bem como a intervenção neles pelo Estado como agente também tem falhas, distorções e ineficácias, que para eles são piores do que qualquer uma que possa ocorrer no mercado (...). O neoliberalismo moderno propugna que a ação do governo sobre a economia através das instâncias e dos instrumentos aceitos de política econômica (política econômica e fiscal, política comercial e cambial, política de concorrência, política de meio ambiente etc.), seja a menor possível (...). Os grandes problemas que temos hoje em dia são interpretados pelos neoliberais como resultado de algum tipo de intervenção estatal ou de intervenção das autoridades locais na economia, o que cria distorções na destinação de recursos e atrasos no crescimento da produtividade global da economia. O Estado não é a solução, o Estado é o problema — é um slogan que resume esta maneira de pensar". DE SEBASTIAN, Luís. Neoliberalismo Global: Apuntes Críticos de Economía Global. Apud SALOMONI, Jorge Luis. Regulação de Serviços públicos e Defesa da Concorrência na Argentina. In: SUNDFELD, Carlos Ari. Direito Administrativo Econômico. São Paulo: Sociedade Brasileira de Direito Público, Malheiros, 2000, p. 213-214. Salomoni complementa a citação sustentando, com acerto, que em ambos os sistemas constitucionais (argentino e brasileiro), "não se duvida de que tais princípios não se encontram dogmatizados no nosso sistema constitucional, ainda mais com a incorporação pela nossa Constituição de diversos tratados de direitos humanos", op. cit., p. cit.

${ }^{45}$ DOURADO Maria Cristina César de Oliveira. O Repensar do Conceito de Serviço Público, p. 91. Interesse Público, 9, p. 91.
} 
A primeira expressão, acima citada, pode ser, com restrições, traduzida como titularidade estatal do serviço público, pois é certo que não estamos diante da titularidade estatal propriamente dita, mas sim dos efeitos jurídicos da mesma. ${ }^{47}$ A segunda expressão pode ser traduzida por encargos, quer do poder concedente, quer do concessionário.

Outra expressão, atualmente vulgarizada, potestad, com toda a certeza, traz somente confusões e dúvidas. As expressões brasileiras Poder e competência, utilizadas pela Constituição e pela legislação infraconstitucional, com claro sentido diverso, não refletem, por excessiva a primeira e insuficiente a segunda, o conteúdo jurídico da referida expressão potestad. $\mathrm{O}$ instituto jurídico da potestad não nasce no direito espanhol, e sim nos direitos alemão e italiano. ${ }^{48}$

A potestad, ao contrário do que aparece em textos doutrinários produzidos acriticamente no Brasil, somente pode ser entendida em antagonismo ao direito subjetivo. $\mathrm{O}$ mesmo não ocorre em relação às expressões brasileiras "Poder" e "competência". Ambas as expressões (potestad e competência), no Direito Europeu, são espécies do gênero Poder, sendo uma a face e a outra a contra-face, constituindo-se a potestad em expressão do poder estatal que independe da existência de uma relação jurídica específica, como, por exemplo, o poder expropriatório do Estado ou o caráter exorbitante de algumas das cláusulas de um determinado contrato administrativo, previstas em leis de licitações e contratos administrativos. Já o direito subjetivo, como é elementar, nasce de uma relação jurídica específica, travada sob a égide da potestad, como, por exemplo, o direito de exigir a imissão na posse no bem desapropriado ou a alteração unilateral do contrato. ${ }^{49}$

O mesmo Garrido Falla aduz que: "Para S. Romano, potestad e direito subjetivo são espécies do mais extenso gênero dos poderes atribuídos pelo ordenamento jurídico em relação aos bens ou aos interesses por ele protegidos e tanto uns como outros são, definitivamente, manifestações da capacidade jurídica. Agora, assim como os poderes se apresentam em um plano genérico, sem objeto singularmente determinado, sem resolver

\footnotetext{
46 Id., p. 91.

${ }^{47} \mathrm{Na}$ verdade, como diz Carlos LABAURE ALISERIS, a expressão passa a ser utilizada na doutrina espanhola, a partir de 1950, através do consagrado, e lamentavelmente pouco divulgado no Brasil, VILLAR PALASI, como o elemento distintivo que qualifica uma atividade como serviço público, ou seja, os efeitos da lei formal que declara a titularidade estatal retirando esta mesma atividade do âmbito da liberdade de iniciativa. Estudios sobre la Reforma del Estado. Montevideo: Amalio Fernandez, 2002, p. 68.

${ }^{48}$ GARRIDO FALLA, Fernando. Tratado de Derecho Administrativo. Madrid: Tecnos, 1994, v. I, p. 390.

${ }^{49}$ Op. cit., p. 390-391.
} 
pretensões concretas frente a outros sujeitos e, portanto, sem obrigações correlativas, em troca os direitos subjetivos se desenvolvem sempre numa concreta e particular relação jurídica a respeito de um objeto determinado e frente a uma pessoa dada que, reciprocamente, é titular das obrigações correspondentes. Resulta daí, que a potestad ocupa uma situação preliminar frente a relação jurídica. Como assinala Giannini o ato de exercício da potestad é o lugar de nascimento de novas relações e situações jurídicas: pelo seu exercício opera-se uma atualização, em virtude da qual surge uma nova relação entre o titular da potestad e os sujeitos que o exercício da mesma se refere. A potestad consiste, portanto, em um poder de atuação que, exercitado de acordo com as normas jurídicas, produz situações jurídicas nas quais outros sujeitos tornam-se obrigados. Com anterioridade ao exercício da potestad, estes últimos sujeitos se encontram em uma situação abstrata de submissão, contudo, uma vez exercida a potestad, passam a uma situação concreta de obrigados." 50

Para Eduardo García de Enterría e Tomás-Ramón Fernandez, não discrepando do até aqui visto, "O conceito de potestad se perfila através do seu contraste dialético com o direito subjetivo. Ambas as figuras são espécies do gênero poder jurídico, em sentido amplo, isto é, faculdade de querer e operar que são conferidas pelo ordenamento jurídico aos sujeitos. A partir deste núcleo comum, todas as demais notas servem para diferenciar potestad e direito subjetivo. Assim, o direito subjetivo se caracteriza por ter sua origem numa relação jurídica concreta recaindo sobre um objeto específico e determinado, consistindo numa pretensão de concreção e correspondendo a um dever atribuído a um sujeito passivo, que é, neste sentido, um sujeito obrigado."

Ainda, "potestad não se origina de nenhuma relação jurídica, nem em pactos, negócios jurídicos ou fatos singulares, mas procede diretamente do ordenamento jurídico. Não recai sobre nenhum objeto específico e determinado, sendo que possui um caráter genérico e se refere a um âmbito de atuação definido em grandes linhas genéricas." ${ }^{51}$

Nestes termos, a utilização da expressão alienígena potestad, como sinônimo de alargamento do exercício do poder regulamentar com a pretensão de conferir constitucionalidade e legalidade a estatuição primária de Direito por parte de uma autarquia do Poder Executivo, é inadmissível. Na Constituição Federal não estão arrolados poderes e competências, fora 50 Id., p. 390-391, traduzi. 
das exceções previstas pelo próprio texto, para o exercício de funções normativas por parte do Executivo. Assim, não se pode imaginar que se dê o mesmo através de um poder inexistente, exercendo-se competência da qual não se é titular. Do mesmo modo, não se pode invocar direito subjetivo do particular em exigir do Poder Executivo o exercício de função normativa não autorizada pela Constituição. A tutela perseguida, neste caso, deve ser encontrada junto ao Poder Judiciário, através do mandado de injunção ou da ação direta de inconstitucionalidade por omissão.

Em síntese: tentar legitimar direitos, não previstos constitucionalmente, no inexistente - para o Direito brasileiro - instituto da potestad é, no mínimo, desconhecer princípios comezinhos de Direito e demonstrar, mesmo que de modo irrefletido, desprezo pelo Estado de Direito.

Assim, o designativo potestad somente poderia ser traduzido, aproximadamente, e necessitando, por certo, de determinadas explicações, como o regime de sujeição (supremacia, como menciona Celso Antônio Bandeira de Mello) geral e especial: "É corrente na doutrina alemã (de onde se originou, por obra sobretudo de Otto Mayer) e nas doutrinas italiana e espanhola, a distinção entre a supremacia geral da Administração sobre os administrados e a supremacia especial (assim chamada na Itália e, às vezes, na Espanha) ou relação especial de sujeição (como é referida na Alemanha e, às vezes, na Espanha). De acordo com tal formulação doutrinária, que a doutrina brasileira praticamente ignora, a Administração, com base em sua supremacia geral, como regra não possui poderes para agir senão extraídos diretamente da lei. Diversamente, assistir-lhe-iam poderes outros, não sacáveis diretamente da lei, quando estivesse assentada em relação específica que os conferisse. Seria esta relação, portanto, que, em tais casos, forneceria o fundamento jurídico atributivo do poder de agir, conforme expõe, na Itália, Renato Alessi entre tantos outros." ${ }^{52}$

A identidade citada (potestad e supremacia geral e especial) aparece no magistério de Ricardo Rivero Ortega: "As potestades administrativas situam os cidadãos em uma relação de sujeição que os obriga a acatar os efeitos jurídicos do seu exercício, ainda que sejam benéficos, concretandose em atos declarativos, ainda que prejudiciais, pela imposição de atos de gravame. Manifestações do exercício de potestad são tanto as licenças e subvenções, como as multas, expropriações e inspeções; umas e outras

\footnotetext{
${ }^{51}$ GARCÍA DE ENTERRIA, Eduardo; FERNANDEZ, Tomás-Ramón. Curso de Derecho Administrativo. 8. ed. Madrid: Civitas, 1997, t. I, p. 433-434, traduzi.

52 BANDEIRA DE MELLO, Celso Antônio. Curso de Direito Administrativo, p. 720.
} 
são expressões jurídicas do legítimo atuar da Administração, sempre e quando se respeitem os limites do seu exercício, pois todas as potestades administrativas são, por definição, limitadas, em maior ou menor medida, pelo ordenamento." 53

Vê-se, pois, que a utilização irrefletida da expressão potestad, no Brasil, ocasiona um sem número de confusões e equívocos. Tal fato se explica, uma vez que o operador do Direito alemão, italiano ou espanhol, ao deparar com o designativo potestad, imagina todos os entornos e, principalmente, a origem de determinado regime de sujeição. Ao reverso, o brasileiro, ao deparar com a mesma expressão, necessita, para compreendêla, construir dialeticamente todo um sistema para que possa visualizar o mesmo entorno.

Na verdade, no Direito dos países citados, há regime de sujeição geral em virtude do exercício, pelo Estado, da potestad. Tanto que, o art. 106, I, da Constituição Espanhola, determina que “os Tribunais controlam a potestad regulamentar e a legalidade da atuação administrativa, assim como a submissão desta aos fins que a justificam”. Por outro lado, o art. 97, estabelece que "o Governo dirige a política interior e exterior, a Administração civil e militar e a defesa do Estado. Exerce a função executiva e a potestad regulamentar de acordo com a Constituição e as leis." ${ }^{4}$

Temos então, pois, que, quando dirige a política interior e exterior, a Administração civil e militar e a defesa do Estado exercem Poder. Quando exerce a função executiva, competência. Quando regulamenta a lei, potestad. Mais, no Brasil, é o chefe do Poder Executivo, o que vale dizer o chefe do Governo, e não o Executivo, que tem, privativamente, o poder de regulamentar a lei. Lá, quem possui a potestad, para tanto, é o Governo, até porque, Monarquia parlamentarista, na Espanha, e República parlamentar, na Itália, o governo é extensão do Parlamento.

Outra questão, de resto sempre esquecida. Nos regimes parlamentaristas há divisão de Poderes entre o chefe de Estado e o chefe de Governo. Mas não de potestad, cujo titular é sempre o chefe de Governo.

Lembro, derradeiramente, que a potestad reglamentaria somente foi introduzida na Argentina quando da reforma constitucional de 1994, que, muito embora não tenha implantado o parlamentarismo, criou a figura do Jefe de Gabinete de Ministros. ${ }^{55}$

Despropositada e desarrazoada, deste modo, a tentativa de visualizar,

53 RIVERO ORTEGA, Ricardo. Administraciones Públicas y Derecho Privado. Madrid: Marcial Pons, 1998, p. 99, traduzi.

${ }^{54}$ ESPANHA. Constituição Espanhola, traduzi.

A \& C R. de Dir. Administrativo e Constitucional, Belo Horizonte, ano 5, n. 22, p. 59-99, out./dez. 2005 
numa inexistente potestad, a possibilidade de agentes incompetentes exercerem a "potestad" regulatória, quando não titulares da referida competência. No Brasil, é na lei, e somente na lei, que se depreende o citado regime. Portanto, potestad queda num ponto intermediário entre poder e competência, espaço este inexistente, e, portanto, impossível de ser vislumbrado e desbravado no Direito pátrio.

Igualmente, assusto-me quando, na tentativa de justificar o que não pode ser justificado, no caso a violação da Constituição, com a adoção de teorias econômicas que não encontram domicílio na mesma (como se os incisos do seu art. $1^{\circ}$ fossem miragens), juristas lançam mão de institutos econômicos, geralmente em terminologia inusual (como, por exemplo, flexibilização das relações de trabalho, para não assumir o que se pretende, ou seja, a violação dos direitos trabalhistas), com a pretensão de transformálos, como se tal alquimia fosse possível, em institutos jurídicos. ${ }^{56}$ Surge aqui, mais uma vez, a "tucanagem" ${ }_{57}$ de se colocar acima da Carta receituário de aprofundamento das crises sociais e econômicas que vivem as nações periféricas.

O melhor receituário regulatório anda em sentido exatamente oposto a todas estas tentativas de desnacionalizar o Direito, notadamente o Público. Como registra Calixto Salomão Filho, "Teorias mais simples, baseadas em valores e comportamentos éticos claramente identificáveis, têm muito maior probabilidade de levar a um ambiente de cooperação entre regulador e regulado." ${ }^{58}$

Obrigo-me a confessar, assim, que foi com certo alívio, e esperança, acrescento, que descobri o já citado estudo de Otávio Yazbek, ${ }^{59}$ onde colho,

\footnotetext{
55 BARRAZA, Javier Indalecio; SCHAFRIK, Fabiana Haydeé. La Potestad Reglamentaria de la Administración a la luz de la Constitución nacional reformada. In: CASSAGNE, Juan Carlos (Org.). Derecho Administrativo: obra Colectiva en Homenaje ao profesor Miguel S. Marienhoff. Buenos Aires: Abeledo Perrot, 1998, p. 353 et seq.

${ }^{56}$ O jornalista José Simão, articulista do jornal Folha de São Paulo, invocando o símbolo do PSDB, — partido político que se denomina social democrata, mas é neoliberal —, o "tucano", criou a expressão "tucanaram" para designar a técnica que os políticos desse partido usam, em construções lingüísticas rebuscadas, para justificar posições políticas antipáticas. Assim, por exemplo, "flexibilização das relações trabalhistas" seria "tucanar a exploração dos empregados pelos patrões". "Demanda por trabalho reprimida" ou "excesso de força humana que deseja ser remunerada pelo seu esforço laborativo" é a "tucanagem" do desemprego e etc....

${ }^{57}$ Maria Cristina César de Oliveira Dourado aponta que um dos efeitos perversos da tentativa de sepultar o serviço público "consiste justamente no aprofundamento das desigualdades entre o Norte e o Sul, entre países centrais e periféricos do sistema mundial". Op. cit., p. 92. Cita, a autora, a expressiva Oração do notável cientista do Direito e patriota Paulo Bonavides de que a globalização "poderá significar para as economias periféricas o começo da mais nova e irresgatável servidão, aquela aparelhada por um colonialismo tecnológico e informático, que fará os fortes mais fortes e fracos mais fracos. Entre estes, sem dúvida, hão de arrolar-se, caudatariamente, na miragem do desenvolvimento, países como o Brasil, a Argentina e o México". Op. cit., p. 139.
} 
de início, a seguinte observação: "A despeito da crescente imposição a todo o mundo de modelos jurídicos e negociais uniformizados, provenientes dos países centrais, a compreensão dos processos de circulação de tais modelos vem sendo quase que sistematicamente deixada de lado." ${ }^{60}$ Para chegar à conclusão que pretendo, vou utilizar o conceito invocado por Yazbek (tendo como base a criação de James Gardner) ${ }^{61}$ Do estudo de Gardner retiro o conceito de transferência por infusão, ou seja, aquela em que "a iniciativa e esforços partem da sociedade transmitente, ou de alguns de seus setores, ocorrendo, porém, nesse processo de transferência, uma ativa participação de setores da sociedade receptora", ${ }^{62}$ acudindo dizer que "cláusulas (...) próprias do regime da Common Law, têm seu uso cada vez mais difundido, a despeito da possibilidade, em alguns casos, de questionamento de sua plena efetividade ante as estruturas e garantias próprias do ordenamento vigente." ${ }^{3}$ É por isso que, mais uma vez, é preciosa a assertiva de Yazbek no sentido de que a utilização do Direito estrangeiro "com escasso espírito crítico afigura-se pouco razoável, quando não redundante ou, em casos extremos, contraditória." ${ }^{64}$ No mesmo sentido, encontramos o magistério de Eros Roberto Grau, para quem "somente ao preço de malabarismos intelectuais inadmissíveis insiste, certa doutrina, na defesa daquelas inovações." ${ }^{55}$ Soma comentar que este velho vício brasileiro sempre escamoteou uma velha prática nacional, que Yazbek aponta com precisão ímpar: a falsidade do liberalismo brasileiro, fundada no colonialismo, no escravismo, no servilismo e na discriminação, visando sempre convir a interesses externos, mesmo quando estes contradizem os nacionais e até mesmo os eliminam.

Colho, novamente, em Otávio Yazbek, da lavra de Oliveira Vianna, a antiga, mas não desatualizada indignação, de que: "No trabalho de construção do nosso aparelhamento político temos seguido um processo

\footnotetext{
58 SALOMÃO FILHO, Calixto. Regulação e Desenvolvimento, p. 56.

${ }^{59}$ Através da leitura prévia do excelente trabalho de Diogo Rosenthal Coutinho, A Universalização do Serviço Público para o Desenvolvimento como uma Tarefa da Regulação, p. 78, nota 24

${ }^{60}$ YAZBEK, Otávio, op. cit., p. 540.

${ }^{61}$ GARDNER, James. Legal Imperialism - American Lawyers and Foreign Aid in Latin American. Importa fazer constar que para Otávio Yazbek, "parece bastante difícil enquadrar processos complexos em um sistema tão arbitrário como o apresentado por Gardner. As combinações viáveis, porém, assim como a possibilidade de classificação, ainda que preliminar, de processos usualmente ignorados tornam a referência bastante importante". Op. cit., p. 548.

62 Id., p. 546-547.

63 Ibid., p. 547.

64 Ibid., p. 547.

${ }^{65}$ GRAU, Eros Roberto. As Agências, essas Repartições Públicas. Regulação e Desenvolvimento, p. 28.
} 
inteiramente oposto ao dos grandes povos da Antigüidade, como o romano ou grego, ou dos grandes povos modernos, como o inglês, o norteamericano, o alemão. Entre nós, não é no povo, na sua estrutura, na sua economia íntima, nas condições particulares de sua psique, que os organizadores brasileiros, os elaboradores dos nossos códigos políticos, vão buscar os materiais para as suas formosas e soberbas construções: é fora de nós, e nas jurisprudências estranhas, é em estranhos princípios, é nos modelos estranhos, é nos exemplos estranhos, é em estranhos sistemas que eles se abeberam e inspiram. Parece até que é somente sobre esses paradigmas forasteiros que a sua inteligência sabe trabalhar com perfeição" ${ }^{66}$

Eros Roberto Grau ensina que "a multiplicidade de discursos superficiais produzidos em torno das inovações do neoliberalismo e da globalização em nada contribui para a reflexão sobre o Direito, antes a dificulta". Isto porque, "o fato é que o açodado transplante de experiências estrangeiras seria perfeito não fosse uma pedra no caminho: a Constituição do Brasil". ${ }^{67}$

Sobre esta temática escrevi ${ }^{68}$ que a Constituição, como diploma de maior hierarquia de uma ordem jurídica, somente poderá ser legítima quando não contrariar princípios morais que são constantemente criados e recriados pela sociedade, mas corre sério risco de perder legitimidade, e até mesmo deixar de ter qualquer importância normativa se não souber enfrentar os desafios presentes na atual ordem global, no sentido de depurar, entre as diversas e plurais tendências atuais, aquelas que podem complementar o núcleo duro de seu Texto, daquelas que podem destruir o citado núcleo.

Este é o desafio para o qual os publicistas deverão estar preparados. A pós-modernidade coloca uma variedade imensa de discursos, entre os quais, não se lhe escapam os direitos humanos. Importa, pois, demonstrar que as propaladas vantagens trazidas nas novas ondas pós-modernas, tanto cultural como material, só podem ser verificadas na virtualidade dos discursos, nas apologias de seus cultores, nas páginas dos seus defensores. A práxis demonstra, e aqui não discursivamente, que as colocações teóricas surgidas não encontram sucesso (ou eficiência para utilizar uma expressão juridicamente pós-moderna bastante em voga e, atualmente, com alçada

${ }^{66}$ OLIVEIRA VIANNA. O Idealismo da Constituição. São Paulo: Nacional, 1939, p. 7, apud YAZBEK. Ibid., p. 551.

67 Op. cit., p. 28

${ }^{68}$ MOTTA, Paulo Roberto Ferreira. Direito e Moral: qual o Conteúdo para a Constituição? A\&C 8, p. 177 et seq.

A \& C R. de Dir. Administrativo e Constitucional, Belo Horizonte, ano 5, n. 22, p. 59-99, out./dez. 2005 
constitucional) quando aplicadas concretamente.

Deste modo, ganha força, na mentalização pós-moderna, a tendência, não nova, de que a Constituição não pode impedir que as gerações futuras venham a dispor livremente sobre seus interesses, por força da petrealização da moral das gerações pretéritas.

Tal discurso, como todo discurso, tem duas faces, uma verdadeiramente concreta, outra meramente discursiva. Isso porque, se as gerações futuras possuem a possibilidade de disporem livremente sobre seus interesses (e isso deve ser reconhecido como potencialmente verdadeiro e principalmente justo), é mero exercício de futurologia irresponsável sustentar que essas mesmas gerações terão interesse em desprestigiar direitos presentes no atual Texto Constitucional. Melhor deixar que o futuro se encarregue de mostrar quais serão as interpretações constitucionais que farão nossos sucessores.

Quando do julgamento da ADIN no 3105, pelo Supremo Tribunal Federal, que tratava da contribuição previdenciária dos inativos, o Ministro Carlos Britto, em posição lapidar, fez lembrar que "as cláusulas pétreas (...), na Constituição de 1988, não cumprem função conservadora, mas sim impeditivas do retrocesso, ou seja, garantem o progresso". ${ }^{69}$

Não sendo antinômica ao neoliberalismo, evidente que a pósmodernidade no jurídico e no econômico satisfaz os interesses do mesmo, quando trabalha no sentido de desprestigiar os princípios basilares do Direito Público, num cansativo discurso sobre a falência sistêmica destes mesmos princípios. Aqui, mais uma vez, os resultados também são virtuais, eis que a desconstrução principiológica (negativa da hierarquia normativa nascida do gênio de Hans Kelsen, desvalorização da legalidade transformando o princípio em mero indicador exegético, sem maiores conseqüências, extirpação da reserva da lei em sentido formal, dentre outros, tudo em nome da eficiência técnica) não trouxe resultados materialmente auferíveis que demonstrassem, na prática, que as sociedades melhoram seus indicadores sociais, econômicos e, sobretudo, culturais.

Além do mais, diminuir o alcance do princípio constitucional da separação dos Poderes implica em interpretar a Constituição que o consagra de modo totalmente equivocado. Fábio Konder Comparato sustenta que: "Em razão de sua supremacia normativa, o princípio da separação de poderes situa-se no ápice do ordenamento jurídico nacional, sobrelevando

${ }^{69}$ URL: <http://www.stf.gov.br/Jurisprudencia>. 
todas as regras, até mesmo de natureza constitucional, que não tenham o valor de princípios. Na hipótese de uma eventual colisão da separação de poderes com outro princípio fundamental, em determinado caso concreto, o intérprete deve escolher a solução que melhor assegure a proteção dos direitos fundamentais, segundo a técnica de sopesamento, que os alemães denominam Güterabwägung, e os anglo-saxônicos balancing." "70

Sustenta, ainda, que "sob o aspecto da ilimitação do seu grau de aplicabilidade, enquanto princípio jurídico, a separação de Poderes não se reduz a determinados efeitos, taxativamente declarados ou não no texto constitucional." $" 1$

E mesmo que, eventualmente, e por enquanto apenas na virtualidade discursiva, as formulações neoliberais tragam aumentos qualitativos de indicadores sociais, econômicos e culturais, não se poderia admitir que, por este fato, fosse possível crer que o Estado Social morreu, assim como o serviço público.

Como aduz Fábio Konder Comparato "nunca se poderá dizer que a dignidade de uma pessoa já foi integralmente respeitada, ou que uma sociedade é totalmente democrática." ${ }^{2}$ Até porque a evolução cronológica dos direitos humanos demonstra que gerações dos mesmos se sucedem, mas não se excluem, assim como novas, e mais legítimas, formas de expressão da democracia surgem no processo de acumulação cultural da humanidade.

Os homens do final do século XX, início do século XXI, acostumados a vivenciar e alcançar benefícios sociais, libertando-se da miséria, pelas novas gerações dos direitos humanos e pelas novas formas de exercício da democracia, certamente não reconheceriam como democrático o Estado do século XIX, ou, no mínimo, considerariam a democracia do apontado período histórico como incompleta e imperfeita. Neste processo evolutivo de cultura, notadamente jurídica, as gerações futuras terão a exata compreensão de nossas insuficiências e deficiências na defesa dos direitos humanos. É por isso que soa estranha a assertiva de Fábio Ulhoa Coelho, antes transcrita: "O Estado ter responsabilidade sobre essas áreas da vida é noção sem sentido para o homem do século XIX, por exemplo."”3 $\mathrm{O}$ surpreendente seria, creio, o contrário, ou seja, que o homem do séculos XX e XXI considerasse haver algum sentido na escravidão existente no século XIX. A mulher do século XX não localiza significado no dote ou

${ }^{70}$ Op. cit., p. 8.

${ }^{71} \mathrm{Id}$.

72 Ibid.

A \& C R. de Dir. Administrativo e Constitucional, Belo Horizonte, ano 5, n. 22, p. 59-99, out./dez. 2005 
na promessa de casamento acertada pelos pais, prática do século anterior. $\mathrm{Ou}$, ainda, a criança do último século vislumbrar alguma justiça na jornada diária de trabalho de 14, 15 horas dos meninos da penúltima centúria.

Nestes casos fica patente que a tendência discursiva atual, bem como a importação de modelos do common law, é a de transformar a vontade livre do indivíduo no único paradigma admitido, olvidando-se, por completo, da construção originariamente kantiana de que isso não é possível, eis que a possibilidade de se usar a coerção só é admitida com a concordância geral e abstrata de todos, através da lei em sentido formal.

O professor Luiz Gonzaga Belluzo sustenta que: "É duvidoso que o indivíduo projetado pelo Iluminismo tenha, de fato, triunfado. Triunfaram, sim, a insegurança e a impotência. Tal sensação de insegurança é o resultado da invasão em todas as esferas da vida, das normas de mercantilização e da concorrência, como critérios dominantes da integração e do reconhecimento social. Nos países em que os sistemas de proteção contra os freqüentes 'acidentes' ou falhas do mercado são parciais ou estão em franca regressão, a insegurança assume formas ameaçadoras para o convívio social.”

Ainda, "há quem se irrite com a menção do Conselho de Washington como origem e destino das políticas liberais na América Latina. Mas basta olhar em volta e observar que as novas estratégias de 'integração' à economia mundial e de 'modernização' das relações entre Estado e mercado foram iguais ou quase, em todos os países da região e produziram os mesmos resultados econômicos e sociais desapontadores. Foi grande a decepção causada pela descoberta de que a vitória contra a inflação e as reformas pró-mercado não produzem necessariamente mais empregos, melhores condições de vida e um futuro melhor para os filhos. A sensação dos brasileiros é de profunda insegurança. E a insegurança produz o mal-estar de forma ampliada numa sociedade desigual e com perspectivas de baixo crescimento e lenta mobilidade vertical para a maioria. Para o cidadão afetado pelas conseqüências devastadoras das crises financeiras, parece inteiramente fantástica a idéia de controlar as causas dessas golpes do destino. As erráticas e aparentemente inexplicáveis convulsões das bolsas de valores ou as misteriosas evoluções dos preços dos ativos e das moedas são capazes de destruir suas condições de vida. O consenso dominante trata de explicar que, se não for assim, sua vida pode piorar ainda mais. A formação desse consenso é, em si mesmo, um método eficaz de bloquear ${ }^{73}$ Op. cit., p. 192. 
o imaginário social, numa comprovação dolorosa de que as criaturas da ação humana coletiva - as instituições produzidas pelo devir histórico — adquirem dinâmicas próprias e passam a constranger a liberdade de homens e mulheres." 74

Desnudada, assim, a idéia pós-moderna de que a ordem jurídica não pode prescindir de reproduzir a ordem moral, é possível colocar que a necessária depuração desta pela jurídica deve manter a principiologia existente, no sentido de defender os direitos previstos na Constituição, razão pela qual a irresponsável importação (ou transferência por infusão) agride a Lei Maior naquilo que a mesma possui de mais importante, ou seja, o seu núcleo duro.

Isso não implica, como é óbvio e elementar, que tais direitos alienígenas não possam sofrer um processo (e não procedimentalização como parece bastar aos seus irreflexivos importadores) interpretativo diferente, no sentido de adaptação à realidade nacional e às novas necessidades surgidas com as privatizações e regulações das mesmas, e não, certamente, o caminho inverso, de reinterpretação no sentido de transformar tais direitos em meros procedimentos, axiologicamente neutros e destituídos de eficácia material.

Para tanto, necessário se faz conhecer cognitivamente (e o pleonasmo aqui utilizado é proposital, no sentido de conhecer o discurso não apenas na sua forma e conteúdo, mas também, e principalmente, na sua essência) o novo aporte que se pretende transpor, qual paradigma o estriba e reconhecer nele um aliado ou um inimigo da necessária simbiose entre os dois fundamentais princípios da Constituição da República, no caso o Estado Social de Direito e a Dignidade da Pessoa Humana. No primeiro caso, permitir que adentre no sistema jurídico; no segundo, a necessária repulsa.

Agindo de modo contrário, o que vale dizer irrefletidamente, nas transferências por infusão irresponsáveis, vamos assistir a uma "crescente discrepância" entre as "necessidades dos países em desenvolvimento e receitas regulatórias que lhe são sugeridas (e muitas vezes impingidas)."75 E assim agimos, irresponsavelmente, porque adotamos escolas econômicas e jurídicas alheias à nossa realidade e a nossa cultura. Ou, como preferiu denunciar Oliveira Vianna, "sobre paradigmas forasteiros" com os quais, "parece", a inteligência destas pessoas "sabe trabalhar com perfeição".

É nesse sistema, perverso, que nascem os desprezos e os esqueci-

${ }^{74}$ Carta Capital, 8 jan. 2003, p. 39-41. 
mentos da doutrina clássica brasileira, como se autores como Alberto Venâncio Filho, Caio Tácito, Francisco Campos, Guimarães Menegale, Oswaldo Aranha Bandeira de Mello, Manoel de Oliveira Franco Sobrinho e Themístocles Cavalcanti - e tantos outros não citados neste trabalho - nada significassem hoje, constituindo-se em mercadorias de valor insignificante, e qualquer coveiro virtual do serviço público pudesse suplantar as monumentais obras que foram construídas pelos nominados. Seria transformar a doutrina criada e acumulada pela inteligência de compatriotas numa relação cambial, onde no mercado das palavras, um Ariño Ortiz, conforme a cotação do dia pudesse valer 5,84 Venâncio Filho ou 3,45 Francisco Campos.

Assim, em busca de um prometido, mas nunca cumprido, desenvolvimento, adotam-se posturas típicas dos desprovidos de inteligência, ignorando-se os juristas pátrios e o notável acúmulo cultural de suas obras, transformando outros, pelo simples fato de serem estrangeiros e neoliberais, em profetas de um novo Direito, que, conforme visto em linhas anteriores, de inédito somente possui o rótulo de suas velhas e perversas soluções.

$\mathrm{E}$, por fim, não mostrem apenas um lado do "novo direito comunitário europeu", como se não existisse, por exemplo, ao lado de tantos outros, um Santiago Muñoz Machado, que, baseado na jurisprudência dos mais importantes Tribunais europeus, demonstra que "as tantas declarações e augúrios que se publicam sobre a radical transformação que a constituição econômica comunitária impõe à organização e ao regime dos serviços públicos (...) não transformam os mesmos em instituições completamente diferentes das conhecidas até agora, implantadas conforme os direitos de cada um dos Estados." 76

Além disso, em crítica direta, demonstra o citado autor, aqui desenvolvendo a sua doutrina, que: "A opinião e as teses de G. Ariño, J. M. de la Cuétara e J. L. Martínez López-Muniz utilizam como únicos argumentos a crise de alguns serviços de caráter econômico. Nem sequer de todos eles. Por outra parte, algumas das técnicas que crêem universalizáveis e aplicáveis a todos os serviços públicos, procedem, sobretudo, e algumas vezes, exclusivamente, das regulações comunitárias em matéria de telecomunicações. O que quer dizer, são regulações especializadas." 77

Uma única frase, como a de Muñoz Machado, ruiu e derruiu centenas de páginas, de maneira tão simples, tão fácil, tão evidente, eis que

\footnotetext{
${ }^{75}$ SALOMÃO FILHO, Calixto. Regulação e Desenvolvimento, p. 62.
} 
a perfeição de uma análise tem a força de tornar tudo muito claro e manifesto. Mais uma vez, foi cristalinamente demonstrado, que o neoliberalismo se beneficia da ausência de base científica de alguns juristas para conquistar corações e mentes. Assim, em poucas, mas contundentes e precisas, palavras, Muñoz Machado demonstra realidades sempre esquecidas, quando interessa esquecer.

Não é o serviço público que está em crise, apenas determinados serviços, notadamente o das telecomunicações, tiveram avanços tecnológicos que ultrapassaram o agasalho jurídico que a atividade antes possuía. Se as telecomunicações possibilitam, hoje, a livre competição, em virtude do desenvolvimento tecnológico, não se pode dizer o mesmo de outros serviços públicos estruturais. Não há, ao fim e ao cabo, como justificar, destarte, pelos fatores antes assentados, a morte do serviço público e, conseqüentemente, o desaparecimento do Estado Social. Tal procedimento se constitui na inversão da lógica da ciência, transformando a exceção em regra e a regra em exceção.

Feitas estas considerações, em algumas linhas que talvez tenham ultrapassado, pelo tom de desabafo, os limites impostos pela linguagem acadêmica, passo à análise de alguns institutos jurídicos trazidos, via transferência por infusão, ao panorama brasileiro, após a implementação das reformas neoliberais. A total e absoluta incongruência dos mesmos, bem como os graves atentados à Constituição que ocasionam, são evidentes, para todos aqueles que, pensando em português, pretendem a defesa do núcleo duro da Constituição.

\section{A fuga do direito administrativo}

Constata Jesús Leguina Villa que "nos últimos anos um número importante de entidades e atividades administrativas tem sido transferido pura e simplesmente ao setor privado ou, sem abandonar o setor público, tenha adotado de maneira crescente formas de organização e técnica de gestão próprias do Direito Privado". ${ }^{78}$ Este fenômeno se constitui na fuga do Direito Administrativo e tem como pretensão "encontrar sua justificação no princípio constitucional da eficácia da Administração que obrigaria a reduzir, de um lado, a excessiva dimensão alcançada pela

\footnotetext{
${ }^{76}$ MUÑOZ MACHADO, Santiago. Servicio Público y Mercado, p. 139, traduzi.

${ }^{77}$ Id., p. 140, nota 141, traduzi.
} 
organização administrativa e a ter em conta, as exigências da lei do mercado na estrutura e na ação administrativa."79

Portanto, "para ser eficaz e poder competir com o setor privado, a Administração abandona, assim, seu direito próprio, e busca acolhida na autonomia da vontade e na liberdade de contratação que lhe proporciona o direito privado." ${ }^{80}$ Leguina Villa coloca a questão de modo fundamental, qual seja, a de que "não há dúvida de que a eficácia é um princípio que não se deve subestimar na Administração de um Estado de Direito, pois o que importa aos cidadãos é que os serviços públicos sejam prestados adequadamente" agora, "a eficácia que a Constituição exige da Administração não deve se confundir com a eficiência das organizações privadas nem é, tampouco, um valor absoluto diante dos demais." ${ }^{1}$

No Direito brasileiro, corajosamente nadando contra a corrente das apressadas, rasas e ligeiras interpretações do princípio da eficiência administrativa, constitucionalizado pela Emenda Constitucional n. 19/98, o jovem professor de Direito Administrativo, Emerson Gabardo realizou dicção no sentido de que: "A real interpretação da eficiência no contexto do Estado Social não pode restringir-se à perspectiva autônoma neoliberal, característica da mentalidade pós-moderna. Urge, então, que seja promovida uma interpretação desmitificadora, que entenda a eficiência como um valor dependente de fundamentos por um lado ético, e, por outro, inerentes à justiça como ideal maior do Estado.”

Mais, “assim sendo, o princípio não deve ser considerado uma mera transposição de um parâmetro da administração privada, nem implica uma derrogação de qualquer outro princípio constitucional, notadamente o da legalidade." 82

A jurista espanhola Silvia Del Saz Cordero considera que a fuga do Direito Administrativo, presente em vários países do mundo, apresenta manifesta inconstitucionalidade, eis que nos ordenamentos constitucionais está estabelecida uma reserva constitucional de Direito Administrativo, impondo, assim, limites ao legislador. ${ }^{83}$

\footnotetext{
${ }^{78}$ LEGUINA VILLA, Jesús, op. cit., p. 637, traduzi.

${ }^{79}$ Op. cit., p. 637. Dentro de uma visão mais ampla, nas relações do Direito Público e Privado, a fuga do Direito Administrativo foi estudada com profundidade, de modo um tanto simpático ao fenômeno, por RIVERO ORTEGA, Ricardo, em Administraciones públicas y derecho privado, notadamente nos capítulo introdutório (Uso y abuso del derecho privado por la administración pública). No mesmo sentido, embora com maior crítica, DESDENTADO DAROCA, Eva. La crisis de identidad del derecho administrativo: privatización, huida de la regulación pública y administraciones independientes, todo. 
Também apontando a inconstitucionalidade deste procedimento, a jurista portuguesa Maria João Estorninho destaca que esta fuga é "consciente e perversa". Mergulhando na evolução histórica do Direito Administrativo, deduz que houve tempos em que o Estado e a Administração Pública não se submetiam ao Direito, sendo, portanto, Estado absolutista, despreocupado e indiferente aos anseios das populações. Mais, que o processo somente foi passível de sofrer alteração quando a Administração passou a submeter-se ao Direito Público. Assim, o Direito Privado se constituiu na "cara má" da Administração porque é o mecanismo encontrado para fugir das "vinculações jurídico-políticas". ${ }^{84}$

Importa lembrar o alerta de Mariano Brito "sobre a improcedência de uma sujeição geral da atividade dos entes públicos ao Direito Privado, sem outras precisões, e especialmente se a mesma possui uma conotação de eliminação dos constrangimentos - 'privilégios a menos' — que impeça a execução dos encargos estatais." $\$ 5$

Deste modo, é induvidoso que a fuga verificada, no Direito Brasileiro, também possui esta dupla faceta de inconstitucionalidade e indiferença. A indiferença é evidente, até porque a Administração, quando foge em direção ao Direito Privado, no mínimo, não oferece a todos o direito de competir pelos bônus de tal proceder. A indiferença, assim, nasce exatamente pelo fato de que a isonomia é ignorada.

A inconstitucionalidade é perfeitamente demonstrável, assim como a reserva constitucional de Direito Administrativo na Constituição da República Federativa do Brasil. Celso Antônio Bandeira de Mello defende a tese de que a prestação (ou exploração) do serviço público por pessoas privadas não pode implicar na violação do regime jurídico-administrativo (o que vale dizer, na reserva constitucional de Direito Administrativo) e na transformação dos mesmos em atividade econômica privada. Para o eminente autor, "há serviços que a Constituição já prefigurou como públicos" ${ }^{86}$ e é exatamente o regime jurídico de Direito Público que

82 GABARDO, Emerson. Princípio Constitucional da Eficiência Administrativa. São Paulo: Dialética, 2002, p. 146-147.

83 DEL SAZ CORDERO, Silvia. Las Transformaciones del Derecho Administrativo al Final del Siglo XX, p. 65. Da autora consultar: Desarrollo y Crisis del Derecho Administrativo, su Reserva Constitucional. In: CHINCHILLA, Carmen; LOZANO, Blanca; DEL SAZ, Silvia. Nuevas Perspectivas del Derecho Administrativo: Tres Estudios. Madrid: Universidad Nacional de Educación a distancia, Civitas, 1992, p. 101-190.

${ }^{84}$ ESTORNINHO, Maria João. A Fuga para o Direito Privado: Contributo para o Estudo da Actividade de Direito Privado da Administração Pública. Coimbra: Almedina, 1996, p. 355.

85 BRITO, Mariano R.; DELPIAZZO, Carlos A. Derecho Administrativo de la Regulación Económica. Montevideo: Universidad de Montevideo, 1998, p. 79. 
permite diferenciá-los das atividades econômicas privadas:(...) a chamada 'crise do serviço público' - de que tanto se ocupou a doutrina francesa na década de 50 - ou a suposta crise que estaria hoje a atingir tal noção, sobretudo pelo impacto das idéias econômicas da 'privatização' preconizadas pelo neoliberalismo, consistem precisamente em um retrato fiel deste chocante equívoco: assentar uma noção jurídica não sobre 'elementos de direito', mas sobre dados da realidade fática. Deveras, o que a doutrina então tomou como sendo uma crise foi a dissociação de três elementos que, de regra, se encontravam associados ao se pensar em serviço público: a saber: (a) uma atividade tida geralmente como de interesse geral; (b) o fato de ser prestada por um organismo governamental e (c) dita prestação fazer-se sob um regime característico: o regime de direito público. Ora, serviço público, como noção jurídica, só pode ser um dado regime, nada importando que se altere o substrato sobre o qual se aplica, pois este, obviamente, é mutável tanto quanto a realidade social. (...) Na atualidade, desavisadamente, repete-se a mesma inconseqüência. E entre nós, o que ainda é pior, reproduzindo, como é típico dos subdesenvolvidos, o que é dito no exterior, sem atentar para o fato de que a Constituição Brasileira, não admitiria desclassificar certas atividades da categoria serviço público, óbice este inexistente em outros países." ${ }^{87}$

Finalmente, a crise do Estado Social também pode ser explicada pela perda de legitimidade do mesmo. Mas qual a razão que leva a esta perda? Uma das respostas é encontrada, com certeza, na fuga que o Estado vem empreendendo do Direito Administrativo, colocando inúmeras de suas funções e atividades sob a égide do Direito Privado. "O Estado encontra a sua legitimidade nos serviços que presta à coletividade. O poder público não pode se legitimar pela sua origem, mas somente pelos serviços que presta conformemente às regras de direito." 88 Quanto maior for a fuga, maior será, portanto, a perda de legitimidade.

\section{"O poder regulador" e a função regulatória}

Nota-se, em certos setores da doutrina brasileira, o uso, a meu ver completamente indevido, da expressão poder regulador, cuja origem seria a "delegação" realizada pelo Poder Legislativo para as agências reguladoras, executivas e etc. Respeitosamente, na Constituição da República ${ }^{86}$ BANDEIRA DE MELLO, Celso Antônio. Privatização e Serviços Públicos. RTDP, 22, p. 174.

${ }^{87}$ BANDEIRA DE MELLO, Celso Antônio. Serviço Público e sua Feição Constitucional no Brasil. In: MODESTO, Paulo; MENDONÇA, Oscar (Coord.). Direito do Estado: Novos Rumos. São Paulo: Max Limonad, 2001, t. 2 , p. 15 , nota 2 . 
Federativa do Brasil, o Poder Legislativo não é nem pessoa e nem órgão, mas "Capítulo", no caso o de n. I, do Título IV, que versa sobre a organização dos Poderes. Quem pode delegar algo a alguém, são as Casas (órgãos) que integram o Poder Legislativo (art. 44), ou seja, o Congresso Nacional, o Senado Federal e a Câmara dos Deputados. Mais, na Constituição Federal sequer encontramos a possibilidade do Congresso, do Senado ou da Câmara, delegarem o exercício de qualquer função normativa a qualquer órgão do Poder Executivo, quanto mais a uma autarquia, que é, como óbvio, ente da Administração Pública indireta.

A delegação possível, dentro da Constituição, é aquela que nasce da solicitação do Presidente da República ao Congresso Nacional (e não ao Poder Legislativo, como antes frisei) para a elaboração das leis delegadas (art. 68). Aqui, anoto a existência, sempre esquecida, do parágrafo primeiro do mesmo art. 68, no sentido de que "não serão objeto de delegação os atos de competência exclusiva do Congresso Nacional, os de competência privativa da Câmara dos Deputados ou do Senado Federal”, além da "matéria reservada à lei complementar, nem a legislação sobre organização do Poder Judiciário e do Ministério Público; nacionalidade, cidadania, direitos individuais, políticos e eleitorais; planos plurianuais, diretrizes orçamentárias e orçamentos".

Com a idéia da existência de um poder regulador, vão, certos setores da doutrina, ainda mais além, no sentido de afirmar que esse poder regulador estaria inserido dentro das funções da Administração Pública. Creio, respeitosamente, que Poder não pode ser estabelecido por lei, só a competência. Aliás, e mais uma vez respeitosamente, Poder somente pode ser criado pelo exercente do Poder Constituinte Originário. Este criou apenas três Poderes, e nos mesmos, não se verifica a existência de um denominado regulador. A utilização do termo, assim, somente poderá ser aceita como vício de linguagem, mas jamais como instituto jurídico, ainda mais de alçada constitucional.

Tentando defender a idéia de um inexistente e, portanto, inconstitucional poder regulador, o mesmo é apresentado, costumeiramente, como uma delegação tácita de competências, que seriam exercidas conjuntamente pelos Poderes Legislativo e Executivo. Quero crer, e renovando respeito, que a Constituição Federal, em momento algum, estabeleceu competências conjuntas entre os Poderes Legislativo e Executivo. Pelo contrário, para

${ }^{88}$ DERANI, Cristiane, op. cit., p. 62. 
garantir e efetivar o Estado de Direito, separou.

Assim, inexistindo competência conjunta, torna-se absolutamente impossível delegar-se, ou exercer conjuntamente, aquilo cuja previsão é vedada pelo Texto Constitucional. Por outro lado, o Poder Executivo, como é óbvio, não poderia delegar o exercício da função normativa, que não lhe pertence, a uma de suas pessoas, eis que as agências reguladoras e as executivas integram a Administração Pública indireta, no caso, como autarquias, por mais especiais que sejam na denominação que receberam da suas leis criadoras. O que devemos, penso, é falar em função regulatória.

\section{A função regulatória}

Preliminarmente importa conceituar função, e mais, localizar, na classificação das mesmas, a paragem onde se encontraria a batizada função regulatória. Função, como sintetiza Celso Antônio Bandeira de Mello, é a atividade daquele "que está investido no dever de satisfazer dadas finalidades em prol do interesse de outrem, necessitando, para tanto, manejar os poderes requeridos para supri-las. Existe função quando alguém está investido no dever de satisfazer dadas finalidades em prol do interesse de outrem." 89

Como o poder do Estado é uno, a cultura jurídica construiu a noção de função, a fim de que o ente estatal pudesse exercer o poder por diferentes órgãos, com o claro sentido de desconcentrar o poder, para que a sociedade melhor pudesse controlar o exercente do mesmo. Entendeuse, deste modo, e depois de uma experiência histórica traumática - o Absolutismo - , que pulverizando o poder do Estado em diferentes funções, com diferentes titulares, haveria de se encontrar um equilíbrio. Partindo sempre dessa idéia, o Direito Público tripartiu o poder estatal em três distintas e independentes, mas comunicantes, funções.

Na função executiva, compreendendo uma função de administração e outra de governo, sendo, portanto, bipartida, está o locus onde vamos encontrar a denominada função regulatória. Isto porque, a função administrativa, no dizer de Celso Antônio, é aquela que visa "satisfazer interesses públicos, ou seja, interesses de outrem: a coletividade”, de onde se originam as prerrogativas da Administração, sendo "legítima se, quando e na medida indispensável ao atendimento dos interesses públicos; vale dizer do povo", a Administração utilize dado rol de prerrogativas para atingir, mediante o exercício da função, o legítimo desiderato da existência ${ }^{89}$ Curso..., p. 43. 
do Estado. ${ }^{90}$

A função administrativa, conforme conceituação do constitucionalista português Jorge Miranda, não difere do conceito exposto no parágrafo anterior, eis que ela visa a "satisfação constante e cotidiana das necessidades coletivas; prestação de bens e serviços". ${ }^{91}$

Não é outra, por suposto, a tarefa da regulação, bem como as das demais atividades constantes do rol da função administrativa. Ou, como aludiam as Ordenações Filipinas, "regular a atividade daqueles que vendem as coisas que lhes sobejam para os que delas necessitam". Do mesmo modo com que este diploma legal tão sábio aduzia, o Estado tem o dever-poder de assim proceder, tudo para garantir o interesse público.

Portanto, é induvidoso que a função regulatória é administrativa. Submetida, evidentemente, aos princípios gerais da Ordem Econômica, previstos na Constituição Federal, explicitados nas Casas legislativas, regulamentados pelo Chefe do Poder Executivo e submetida ao controle judicial, quando desbordar das canelatas erguidas pelo ordenamento positivo.

É, também, função instrumental. Dentro do arcabouço jurídico, compete ao Estado, através da Administração Pública, submetida ao regime que lhe é peculiar, utilizar os instrumentos necessários para materializar os princípios da Ordem Econômica estabelecidos a partir do art. 170 da Constituição Federal.

Assim, compete à função regulatória (uma das espécies do gênero função administrativa), sem violar os demais ditames constitucionais, mas, ao contrário, dando-lhes eficácia, ou, no mínimo, não os contrariando (interpretação e aplicação sistemática da Constituição), para tutelar todas as atividades econômicas e os serviços públicos - prestados direta ou indiretamente pelo Estado - , com a finalidade de assegurar e defender: a soberania nacional, a propriedade privada, a função social da propriedade, a livre concorrência, a defesa do consumidor, a defesa do meio ambiente, a redução das desigualdades regionais e sociais, a busca do pleno emprego e todos os outros princípios inerentes aos da soberania, cidadania, dignidade da pessoa humana, valor social do trabalho e da livre iniciativa e do pluralismo político.

É no desnudamento da função regulatória, portanto, que se pode verificar se estamos diante de uma regulação ou de uma regulação neoli-

\footnotetext{
90 Id., p. 93.

${ }^{91}$ MIRANDA, Jorge. Manual de Direito Constitucional. Coimbra: Coimbra Ed., 1997, t. V, p. 23.
} 
beral. Cumprindo-se os princípios fundamentais da República e da Ordem Econômica desta mesma Coisa Pública, a regulação existente é a necessária, e no caso do Direito brasileiro, secular. Agasalhando apenas a livre iniciativa, e, violando ou, no mínimo, contrariando os demais princípios arrolados pela Carta Magna, estaremos diante da regulação neoliberal.

Considerando que a expressão poder regulamentar somente pode ser considerada como vício de linguagem, ou seja, com o claro propósito de referir-se à função administrativa, resta, agora, analisar outro elemento, cuja introdução, no Direito brasileiro, vem sendo tentada pela regulação neoliberal: a delegificação.

\section{A delegificação}

A delegificação, também conhecida como deslegalização, pode ser conceituada como uma espécie de passagem de certas matérias da Lei para o Regulamento. Apontam os defensores da tese de que não haveria transferência de poder e nem delegação (que sabem vedadas diretamente no Texto Constitucional brasileiro), mas sim uma "transferência" de sede normativa.

Respeitosamente, a ilação merece contundentes reparos. Não alcanço diferença alguma entre dizer que não há transferência de poder (ou delegação) e sim transferência de sede normativa. Mais, não consigo vislumbrar a possibilidade de tal fato ocorrer sem que se faça tábula rasa da Constituição Federal. Como sustenta Clèmerson Merlin Cléve, "a lei configura sempre um mecanismo de criação do Direito decorrente da atividade do Estado", podendo ser "ato que decorre do exercício da função legislativa propriamente dita - Congresso Nacional — ou eventualmente, por outro poder, como é o caso do Presidente da República (leis delegadas ou medida provisórias)" ${ }^{92}$ Fora destes casos, por evidente, não há lei.

Defendem, também, os cultores de tal heterodoxo instituto, a tese de que, se o Legislativo pode revogar uma lei, também poderia "rebaixar o seu grau hierárquico". Na verdade, e mais uma vez com respeitos, o argumento não convence. $\mathrm{O}$ processo legislativo brasileiro, art. 59, da Constituição Federal, estabelece uma hierarquia normativa, dando guarida, como de resto todas as Constituições civilizadas o fazem, aos ensinamentos de Hans Kelsen. Dentro desse mesmo processo legislativo, as únicas formas previstas são as de fazer a lei e de revogar a mesma, mas nunca a de proceder o rebaixamento do grau hierárquico da lei. Pode-se, por certo, desconstitucionalizar um determinado direito, presente na Constituição, A \& C R. de Dir. Administrativo e Constitucional, Belo Horizonte, ano 5, n. 22, p. 59-99, out./dez. 2005 
desde que não seja uma cláusula-pétrea, retirando-o da mesma através de emenda constitucional supressiva, e o introduzindo no ordenamento positivo através de lei. Do mesmo modo, é possível, também, fazer desaparecer um direito do ordenamento jurídico através de nova lei, que revogue a anterior. Assim, e somente assim, por estes dois únicos e exclusivos processos legislativos, é possível, no primeiro caso, "rebaixar", e, no segundo, "revogar", um direito. Mas não havendo hierarquia entre as demais leis, apenas processos de elaboração diferentes, quer pelo quorum, quer pela iniciativa, não há, nos estritos termos do aludido artigo da Constituição, forma de rebaixar o grau hierárquico da lei.

Haveria, no plano das idéias, somente uma única possibilidade para tanto: emenda constitucional que viesse permitir a edição de regulamento regulatório autônomo. Não tendo havido tal emenda, é evidente a impossibilidade de assim proceder. E esta emenda, frise-se, é inimaginável, eis que segundo o art. 60, parágrafo $4^{\circ}$, III, da Constituição Federal, não será objeto de deliberação a proposta de emenda tendente a abolir a separação dos Poderes.

Na verdade, a delegificação somente pode ser tida como acadêmica discussão de direito comparado. Nada mais do que isto. Seu caráter neoliberal é evidente, transparente, translúcido, e pretende mercantilizar, entre outros, o processo legislativo. A delegificação, neste aspecto, tem o mesmo alcance e significado do que a potestad, eis que pretendem servir de instrumento para justificar o injustificável, ou seja, o exercício da função normativa por um dado ente regulador.

O que parece não ser entendido, tanto na potestad, quanto na delegificação, é que a importação irrefletida de institutos jurídicos, e, no caso, os dois citados são do Direito europeu, não é possível, e sempre terá como obstáculo a Constituição da República Federativa do Brasil, que estabeleceu um regime presidencialista, e não o parlamentarismo existente na União Européia e na Itália, Espanha e França. Sobre o tema, o professor Marçal Justen Filho doutrinou amplamente, ${ }^{93}$ demonstrando, à sobejas, a inaplicabilidade total e absoluta do instituto da delegificação no Direito brasileiro.

Assim, e respeitosamente, mais uma vez, pouco importa, para o Direito brasileiro, que a delegificação seja reconhecida, — até mesmo

${ }^{92} \mathrm{CLÈVE}$, Clèmerson Merlin. A Lei no Estado Contemporâneo, RDAA, 9, p. 347. O tema, sob outro enfoque, mas com conclusões de todo assemelhadas, pode ser encontrado em SOUZA, Artur de Brito Gueiros. $O$ Estado Contemporâneo Frente ao Princípio da Indelegabilidade Legislativa. RDTP, 13, p. 193-202. 
porque no Direito europeu possui adversários —, por juristas do nível de García de Enterría, Crisafulli e outros, cujas homenagens serão, por outros méritos, para todo o sempre, devidas. Defender a tese de que é possível, no Direito brasileiro, delegificar, estribando a mesma na doutrina dos juristas antes arrolados, ignorando a Constituição brasileira, seria o mesmo do que sustentar a idéia de que a delegificação não poderia ser aplicada no Direito espanhol (ou italiano) porque Marçal Justen Filho a ela se opõe. Neste caso, o intérprete estaria ignorando a Constituição espanhola ou italiana.

Portanto, e outra conclusão não se faz possível, creio que a única importância da delegificação reside no interesse acadêmico, no conhecimento do direito comparado, na cultura jurídica. Agora, na dogmática constitucional brasileira não há lugar para ela. Está vedada pelos precisos termos dos arts. $5^{\circ}$, II (legalidade ampla); 37, caput (legalidade estrita); 49, V (sustação do poder regulamentar por exorbitância dos seus limites); 84, IV (limites do poder regulamentar); VI (matérias dos decretos); e, 25 do ADCT (revogação de delegações anteriores à Constituição).

Resta, aqui, fazer consignar a advertência de Clèmerson Merlin Clève: "A missão dos juristas, hoje, é a de adaptar a idéia de Montesquieu à realidade constitucional de nosso tempo. Nesse sentido, cumpre aparelhar o Executivo, sim, para que ele possa, afinal, responder às crescentes e exigentes demandas sociais. Mas cumpre, por outro lado, aprimorar os mecanismos de controle de sua ação, para o fim de torná-los (os tais mecanismos) mais seguros e eficazes." ${ }^{94}$

\section{Conclusão}

Comecei este trabalho falando que o neoliberalismo era ideológico. No jurídico também o é. A Constituição brasileira é um diploma, antes de tudo, pluralístico. Todas as tendências do pensamento nela podem conviver. Contudo, sabiamente, possui poderosos freios para barrar ideologias unilaterais e excludentes, que rebaixam a dignidade da Espécie Humana. Nela, ao fim e ao cabo, não há espaço para que conquistadores encontrem qualquer Porto Seguro. E se mais houvera, mais haveriam chegado... se não fosse uma pedra no meio do caminho: a Constituição da República Federativa do Brasil.

${ }_{93}$ O Direito das Agências Reguladoras Independentes, p. 496 et seq. 
Informação bibliográfica deste texto, conforme a NBR 6023:2002 da Associação Brasileira de Normas Técnicas (ABNT):

MOTTA, Paulo Roberto Ferreira. A regulação e a regulação neoliberal. $A E^{2} C$ Revista de Direito Administrativo e Constitucional, Belo Horizonte, ano 5, n. 22, p. 59-99, out./dez. 2005.

$\overline{94}$ CLÈVE, Clèmerson Merlin. Atividade Legislativa ... p. 42.

A \& C R. de Dir. Administrativo e Constitucional, Belo Horizonte, ano 5, n. 22, p. 59-99, out./dez. 2005 